\title{
Vegetation-climate feedbacks modulate rainfall patterns in Africa under future climate change
}

\author{
Minchao Wu ${ }^{1}$, Guy Schurgers ${ }^{2}$, Markku Rummukainen ${ }^{1,3}$, Benjamin Smith ${ }^{1}$, Patrick Samuelsson ${ }^{4}$, \\ Christer Jansson $^{4}$, Joe Siltberg ${ }^{1}$, and Wilhelm May ${ }^{3,5}$ \\ ${ }^{1}$ Department of Physical Geography and Ecosystem Science, Lund University, Sölvegatan 12, 223 62, Lund, \\ Sweden \\ ${ }^{2}$ Department of Geosciences and Natural Resource Management, University of Copenhagen, Øster Voldgade \\ 10, 1350 Copenhagen, Denmark \\ ${ }^{3}$ Centre for Environmental and Climate Research, Lund University, Sölvegatan 37, 22362 Lund, Sweden \\ ${ }^{4}$ Rossby Centre, Swedish Meteorological and Hydrological Institute, 60176 , Norrköping, Sweden \\ ${ }^{5}$ Research and Development Department, Danish Meteorological Institute, Lyngbyvej 100, 2100 Copenhagen, \\ Denmark
}

Correspondence to: Minchao Wu (minchao.wu@nateko.lu.se)

Received: 14 December 2015 - Published in Earth Syst. Dynam. Discuss.: 18 January 2016

Revised: 27 June 2016 - Accepted: 6 July 2016 - Published: 26 July 2016

\begin{abstract}
Africa has been undergoing significant changes in climate and vegetation in recent decades, and continued changes may be expected over this century. Vegetation cover and composition impose important influences on the regional climate in Africa. Climate-driven changes in vegetation structure and the distribution of forests versus savannah and grassland may feed back to climate via shifts in the surface energy balance, hydrological cycle and resultant effects on surface pressure and larger-scale atmospheric circulation. We used a regional Earth system model incorporating interactive vegetation-atmosphere coupling to investigate the potential role of vegetation-mediated biophysical feedbacks on climate dynamics in Africa in an RCP8.5-based future climate scenario. The model was applied at high resolution $\left(0.44 \times 0.44^{\circ}\right)$ for the CORDEX-Africa domain with boundary conditions from the CanESM2 general circulation model. We found that increased tree cover and leafarea index (LAI) associated with a $\mathrm{CO}_{2}$ and climate-driven increase in net primary productivity, particularly over subtropical savannah areas, not only imposed important local effect on the regional climate by altering surface energy fluxes but also resulted in remote effects over central Africa by modulating the land-ocean temperature contrast, Atlantic Walker circulation and moisture inflow feeding the central African tropical rainforest region with precipitation. The vegetation-mediated feedbacks were in general negative with respect to temperature, dampening the warming trend simulated in the absence of feedbacks, and positive with respect to precipitation, enhancing rainfall reduction over the rainforest areas. Our results highlight the importance of accounting for vegetation-atmosphere interactions in climate projections for tropical and subtropical Africa.
\end{abstract}

\section{Introduction}

The Sahel greening and Congo rainforest browning observed since the 1980s suggest that Africa has been undergoing significant changes in the structure, composition and distribution of vegetation during recent decades (Eklundh and Olsson, 2003; Olsson et al., 2005; Jamali et al., 2014; Zhou et al.,
2014). In addition to influences from anthropogenic activity (e.g. changes in land use), vegetation changes in the region have been linked to changes in recorded climatic conditions, including the trend and interannual variability in precipitation (Herrmann et al., 2005; Hickler et al., 2005; Olsson et al., 2005; Zhou et al., 2014), which in turn have been related to decadal-scale changes in regional circulation (Camberlin 
et al., 2001; Giannini et al., 2003). On longer timescales, anthropogenic climate change has the potential to cause profound structural and compositional changes in vegetation over Africa (Sitch et al., 2008; Scheiter and Higgins, 2009).

Shifts in vegetation cover and composition in terms of the distribution of trees and grasses and their seasonal changes (phenology) can impose significant forcings on the physical climate system by modulating surface-atmosphere energy exchange and hydrological cycling, resulting in biophysical feedbacks along with the climate forcings. The type of vegetation alongside productivity-related structural aspects such as tree density and leaf-area index (LAI) are important determinants for surface albedo, roughness length and evapotranspiration, affecting surface energy fluxes that in turn control lower boundary layer thermodynamics (Eltahir, 1996; Brovkin et al., 2006; Bonan, 2008). Biophysical feedbacks operate locally and may also generate teleconnections via heat and moisture advection, leading to altered atmospheric circulation (e.g. Avissar and Werth, 2005; Nogherotto et al., 2013). Previous studies have shown the importance of vegetation-mediated biophysical feedbacks for the past (e.g. Claussen and Gayler, 1997; Texier et al., 1997) and present (e.g. Eltahir, 1996; Claussen, 1998; Wang and Eltahir, 2000) climate over Africa. Hypothesized mechanisms of vegetation-atmosphere coupling include modulations of the surface albedo (Charney, 1975), changes in the North African monsoon system (Claussen, 1997) and internal climate variability (Zeng et al., 1999).

Feedbacks mediated by shifts in vegetation structure and distribution can likewise play a role for the future regional climate. General circulation models (GCMs) have been applied at relatively coarse lateral grid resolutions to capture these dynamics (e.g. Kucharski et al., 2013). Recent studies have used a regional climate model to investigate the impact of climate-vegetation interaction for West Africa, identifying significant vegetation feedback in modulating local hydrological cycling (e.g. Alo and Wang, 2010; Wang and Alo, 2012; Yu et al., 2015). Additionally, a number of GCMbased studies have investigated the climate effects of anthropogenic perturbations, such as deforestation or afforestation (e.g. Lawrence and Vandecar, 2015). Such studies point to potentially significant forcing of regional climate dynamics, particularly rainfall patterns, as a result of changes in land cover. No study to date has, however, characterized the coupled dynamics of vegetation and climate under future radiative forcing for the entire African domain at a grid resolution high enough to capture regional features and forcings.

In this study, we employ a regional Earth system model (ESM) that couples the physical component of a regional climate model (RCM) with a detailed, individual-based dynamic vegetation model (DVM). This tool enables dynamic representation of biophysical interactions between the vegetated land surface and the atmosphere and their effects on the evolution of climate and land surface biophysical properties to be analysed in an explicit way. We perform simulations un- der the Representative Concentration Pathway (RCP) 8.5 radiative forcing scenario (Moss et al., 2010) with and without vegetation feedbacks enabled, and investigate the potential coupled evolution of climate and vegetation for the African continent over the 21 st century. Our focus is especially on the central African rainforest areas and the surrounding savannah vegetation belt.

\section{Data and method}

\subsection{Model description}

RCA-GUESS (Smith et al., 2011) is a regional ESM based on the Rossby Centre regional climate model RCA4 (Kjellström et al., 2005; Samuelsson et al., 2011) coupled with vegetation dynamics from the LPJ-GUESS DVM to account for landatmosphere biophysical coupling (Smith et al., 2001, 2014).

The RCA4-based physical component of RCA-GUESS incorporates advanced regional surface heterogeneity, such as complex topography and multi-level representations of forests and lakes, which are significant in controlling the development of weather events from the local to mesoscale (Samuelsson et al., 2011). RCA4 has been applied in a range of climate studies worldwide (e.g. Döscher et al., 2010; Kjellström et al., 2011; Sörensson and Menéndez, 2011). The land surface scheme (LSS; Samuelsson et al., 2006) adopts a tile approach and characterizes land surface with open land and forest tiles with separate energy balances. The open land tile is divided into fractions for vegetation (herbaceous vegetation) and bare soil. The forest tile is vertically divided into three sub-levels (canopy, forest floor and soil). Surface properties such as surface temperature, humidity and turbulent heat fluxes (latent and sensible heat fluxes) for different tiles in a grid box are weighted together to provide gridaveraged values. A detailed description is given by Samuelsson et al. (2006).

The vegetation dynamics component of RCA-GUESS employs a plant individual and patch-based representation of the vegetated landscape, optimized for studies at regional and global scale. Heterogeneities of vegetation structure and their effects on ecosystem functions such as carbon and water vapour exchange with the atmosphere are represented dynamically, affected by allometric growth of age-size classes of woody plant individuals, along with a grass understorey, and their interactions in competition for light and soil resources. Plant functional types (PFTs) encapsulate the differential functional responses of potentially occurring species in terms of growth form, bioclimatic distribution, phenology, physiology and life-history characteristics. Multiple patches in each vegetated tile account for the effects of stochastic disturbances, establishment and mortality on local stand history (Smith et al., 2001). This explicit, dynamic representation of vertical structure and landscape heterogeneity of vegetation has been shown to result in realistic simulated vegetation dynamics in numerous studies using the offline LPJ-GUESS 
Table 1. Experimental design for the investigation of the vegetation-climate feedbacks in this study.

\begin{tabular}{|c|c|c|c|c|c|}
\hline Runs & Vegetation feedbacks & Radiative forcing $^{\mathrm{a}}$ & $\begin{array}{l}\mathrm{CO}_{2} \text { forcing } \\
\text { sub-model }\end{array}$ & $\begin{array}{l}\text { Simulated } \\
\text { period }\end{array}$ & $\begin{array}{l}\text { Boundary } \\
\text { condition }\end{array}$ \\
\hline $\mathrm{RP}$ & Dynamic & Historical & Historical & 1979-2011 & ERA-Interim \\
\hline FB & Dynamic & Transient under RCP8.5 & Transient under RCP8.5 & $1961-2100$ & CanESM2 \\
\hline NFB & $\begin{array}{l}\text { Prescribed vegetation simulated } \\
\text { from } 1961 \text { to } 1990\end{array}$ & Transient under RCP8.5 & Transient under RCP8.5 & $1991-2100$ & CanESM2 \\
\hline FB_CC & Dynamic & Transient under RCP8.5 & $\begin{array}{l}\text { Historical until } 2005 \\
\text { and constant afterward }\end{array}$ & $1991-2100$ & CanESM2 \\
\hline
\end{tabular}

Notes: ${ }^{\mathrm{a}}$ using equivalent atmospheric $\mathrm{CO}_{2}$ concentration; ${ }^{\mathrm{b}}$ using actual atmospheric $\mathrm{CO}_{2}$ concentration.

model (Smith et al., 2001, 2014; Weber et al., 2009; Hickler et al., 2012; Wårlind et al., 2014; Wu et al., 2015). Biophysical feedbacks have previously been studied in applications of RCA-GUESS to Europe and the Arctic (Wramneby et al., 2010; Smith et al., 2011; Zhang et al., 2014). A general description of the coupling between the vegetation dynamics component LPJ-GUESS and the physical component RCA is provided in the Appendix. A more detailed description is given by Smith et al. (2011).

\subsection{Model setup, experiments and analysis approach}

The simulations were applied over the African domain of the Coordinated Regional Climate Downscaling Experiment (CORDEX-Africa; Giorgi et al., 2009; Jones et al., 2011) on a horizontal grid with a resolution of $0.44^{\circ} \times 0.44^{\circ}$. The period studied was 1961 to 2100 . Forcing fields in $6 \mathrm{~h}$ time intervals (atmospheric fields and sea-surface temperature (SST) as lateral and lower boundary conditions, respectively) were derived from the historical and RCP8.5 simulations with the CanESM2 GCM (Arora et al., 2011) in the Coupled Model Intercomparison Project Phase 5 (CMIP5; Taylor et al., 2012). Time-evolving forcing fields from the GCM were prescribed for all variables, including SSTs.

The vegetation sub-model LPJ-GUESS was set up with eight PFTs which represent the major elements of natural vegetation across Africa, including the tropical and warmtemperate forests and savannahs and $\mathrm{C}_{3}$ and $\mathrm{C}_{4}$ grasslands. The PFT parameter settings follow Morales et al. (2007) and are summarized in Table A1.

PFTs of the forest tile were simulated with 30 replicate patches. Average values of state variables across the replicate patches were used to determine biophysical parameters, i.e. forest fraction and LAI for trees versus grasses, provided as forcing to the physical sub-model. For the open land tile with herbaceous species, $\mathrm{C}_{3}$ and $\mathrm{C}_{4}$ grass was simulated deterministically and aggregated to characterize open land vegetation. Fire disturbance in response to climate and simulated fuel load (Thonicke et al., 2001) was included.

Following the approach of Wramneby et al. (2010) and Smith et al. (2011), RCA-GUESS was initialized with a spin- up in two stages to achieve a quasi-steady-state representative of mid-1900s conditions. After the spin-up, the model was run in coupled mode from 1961 onwards, with simulated meteorological forcing from the physical sub-model affecting vegetation phenology and structural dynamics and biophysical land surface properties being adjusted to reflect the changes in vegetation, thereby affecting the physical climate dynamics. For comparison, a recent past experiment (RP, Table 1) with the same vegetation spin-up but thereafter driven by boundary conditions derived from ECMWF re-analysis (ERA-Interim) (Berrisford et al., 2009) was conducted for the period 1979-2011.

The simulation protocol was designed to enable biophysical feedbacks of vegetation changes to the evolving $21 \mathrm{st}$ century climate to be inferred. Three simulations were performed to investigate vegetation-climate feedbacks under future climate change (Table 1). The first simulation included the vegetation feedback (FB). It was run for 1961-2100 in coupled mode, allowing the effects of climate and atmospheric $\mathrm{CO}_{2}$ concentration (the latter taken directly from the RCP8.5 dataset) on vegetation state to feed back to the evolving climate. The second simulation was run with vegetation feedback "switched off" (non-feedback run, NFB). It started with the state of FB simulation at 1991 and used a prescribed climatology of daily vegetation for 1961-1990 from the coupled simulation, but without transferring the simulated changes in vegetation in LPJ-GUESS to the land surface configuration, and associated biophysical surface properties, in the LSS of RCA. To attribute the component of the simulated vegetation changes resulting from physiological effects of rising $\mathrm{CO}_{2}$ concentrations of plant productivity and water-use efficiency, we performed a third simulation (FB_CC), which was similar to FB but started from the state of the FB simulation of 1991 and used historical atmospheric $\mathrm{CO}_{2}$ concentrations until 2005, held constant thereafter, to force the vegetation sub-model only.

Our analysis focuses on the future period 2081-2100, comparing this with the present day (1991-2010). The climate change signal is inferred from the difference between the future mean and the present-day mean in the NFB run. 

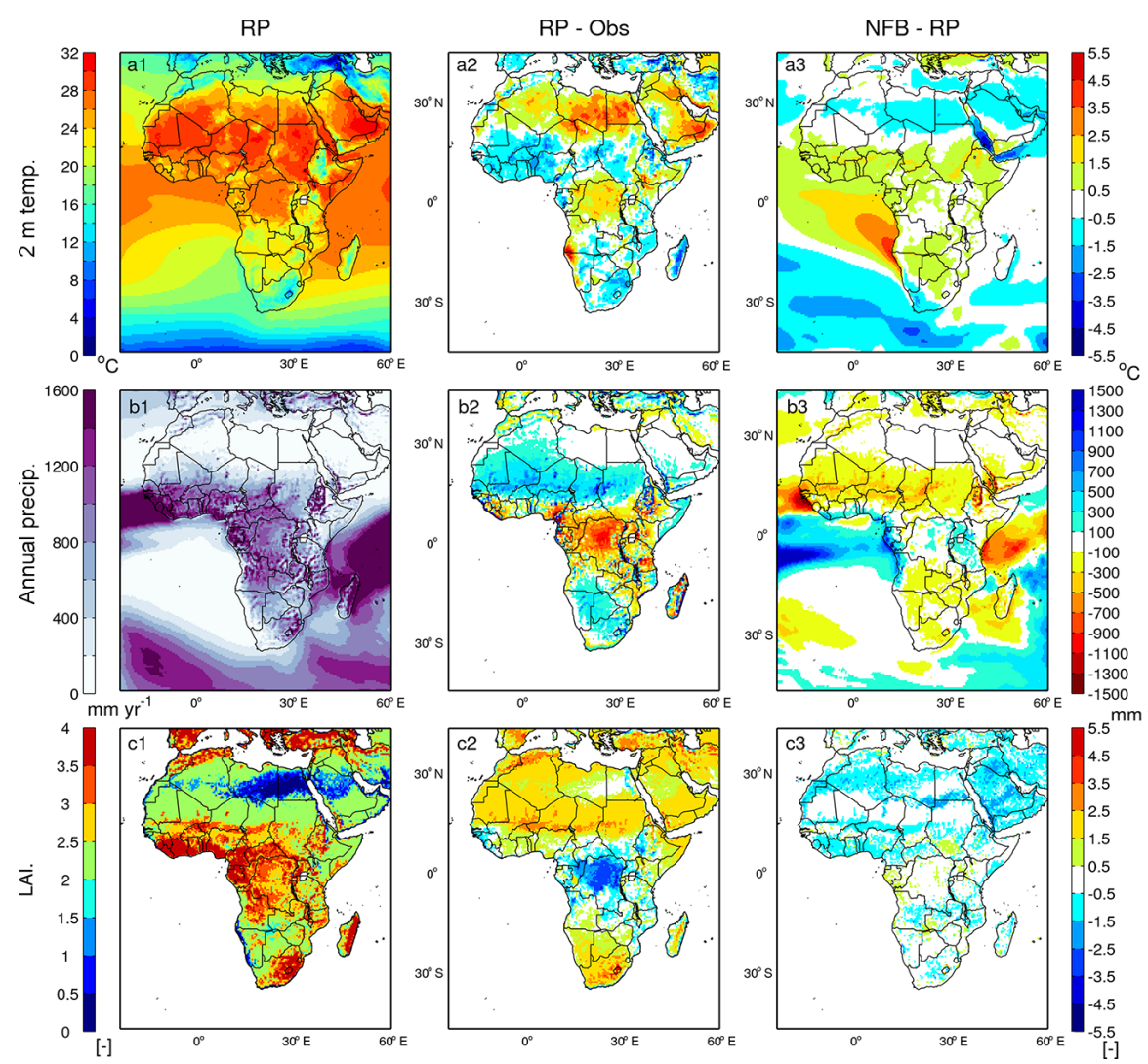

Figure 1. Comparison between simulated and observed (a) annual mean near-surface air temperature, (b) annual precipitation and (c) annual maximum LAI for the period 1997-2010. Variables from the RP experiment (a1-c1) are compared with observations (a2-c2) and with those from the FB experiment (a3-c3), using RP minus observation and FB minus RP. For the comparison with observations (a2-c2), we used CRU temperature (a2) and precipitation (b2), as well as LAI3g (Zhu et al., 2013) (c2).

Vegetation feedbacks are calculated as the difference between the future means of the FB and NFB runs.

\subsection{Methods to evaluate model performance}

Simulated near-surface atmospheric temperatures over open land, precipitation, and LAI were compared against observations within the common available time period 1997-2010. Temperature and precipitation were compared with gridded observations from the CRU TS3.23 (Harris et al., 2014) dataset, focusing on the annual mean and seasonality. For precipitation we also employed the employed the datasets from the Global Precipitation Climatology Project (GPCP; Huffman et al., 2001; version 1.2 of the $1^{\circ}$ daily product for October 1996-June 2011), which uses satellite data to upscale rain gauge measurements and has been extensively used for African precipitation studies (e.g. Nikulin et al., 2012). For the LAI evaluation we used the GIMMS-AVHRR and MODIS-based LAI3g product (Zhu et al., 2013), which has been previously applied to the evaluation of vegetation dynamics in ESMs (e.g. Anav et al., 2013).

To identify biases propagating from the model physics and from the GCM-derived boundary forcing data, we compared the reanalysis-driven RP simulation against observation and against the GCM-driven (CanESM2) FB simulation for the same period.

\section{Results}

\subsection{Model evaluation}

To evaluate the model's performance for the present day, the simulated annual mean and seasonality of $2 \mathrm{~m}$ air temperature, precipitation and LAI are compared against the observations (Figs. 1 and 2). The simulated annual mean temperature (Fig. 1a1) is generally higher in Northern Hemisphere (hereinafter "northern") Africa than in Southern Hemisphere (hereinafter "southern") Africa. The model generally shows a cold bias in the order of $1{ }^{\circ} \mathrm{C}$ for northern and southern savannah (Fig. 1a2), dominated by the Northern Hemisphere summer (JJA, Fig. 2a1, 2a3). Warm biases up to around $3{ }^{\circ} \mathrm{C}$ occur in northern Africa, and warm biases up to around $1{ }^{\circ} \mathrm{C}$ in central Africa, where the warm bias originates mainly from summer (Fig. 2a2).

The simulated precipitation is largest over western and central Africa up to $1600 \mathrm{~mm} \mathrm{yr}^{-1}$ within the simulated rain 

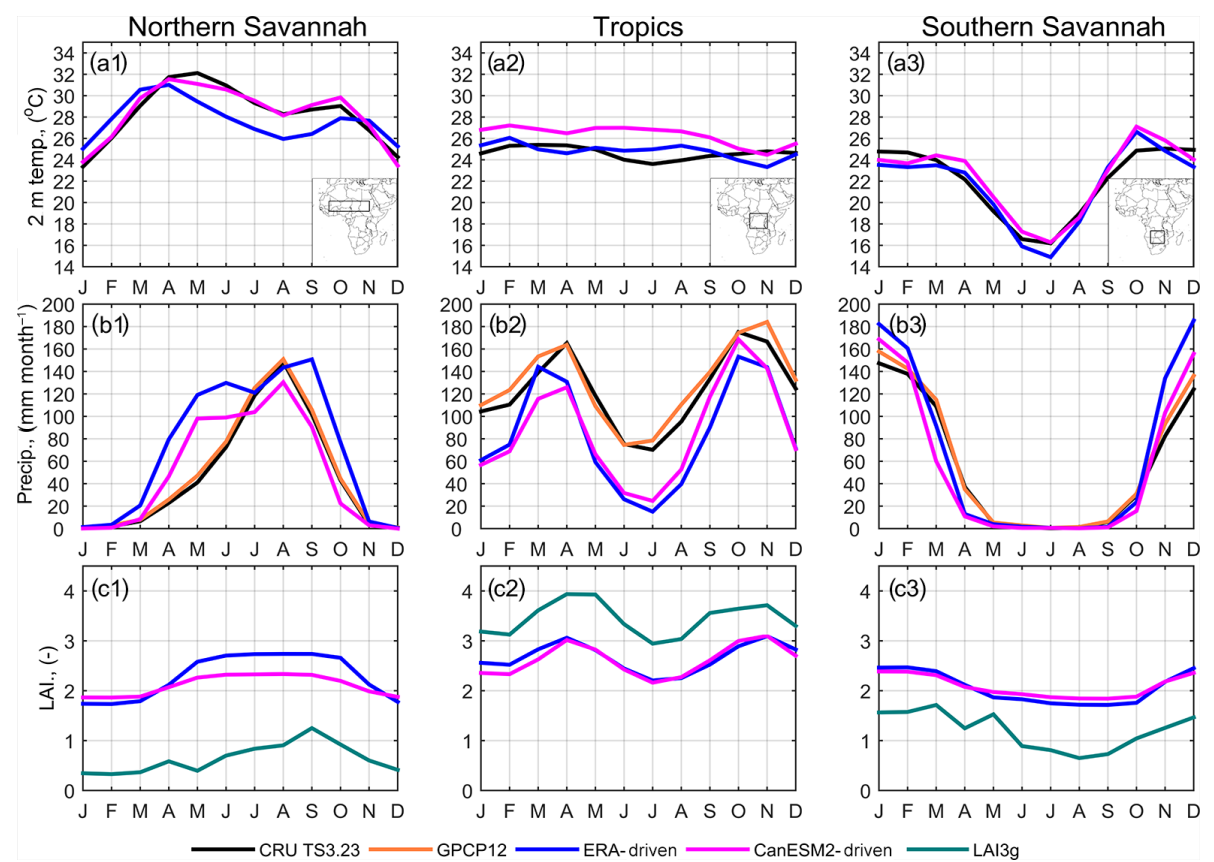

Figure 2. Simulated seasonal cycle and observations for northern savannah (inset in a1), central Africa (inset in a2) and southern savannah (inset in a3) for the period 1997-2010. Two-metre temperature (a1-a3) and precipitation (b1-b3) are as in Fig. 1. For LAI (c1-c3) monthly mean tile-weighted simulated LAI over the averaging period is used to compare with the observation.

belt between $25^{\circ} \mathrm{N}$ and $25^{\circ} \mathrm{S}$, where the Atlantic moisture inflow (monsoon and equatorial westerlies) plays an important role (Fig. 1b1). Comparison with CRU reveals a considerable dry bias $\left(-500 \mathrm{~mm} \mathrm{yr}^{-1}\right)$ for the central African rainforest area and a wet bias $\left(+250 \mathrm{~mm} \mathrm{yr}^{-1}\right)$ for the northern savannah. The simulated patterns and magnitude of precipitation for this area are similar to a previous study using an earlier version of RCA, RCA3.5, without dynamic vegetation (Nikulin et al., 2012). In RCA, the dry bias for annual mean precipitation over central Africa may be partly due to the underestimated daily precipitation during the late afternoon and night in addition to observational uncertainties (Nikulin et al., 2012). The wet bias over the northern savannah is mainly caused by a too early onset of the rainy season (Fig. 2b1), which is possibly caused by the interactions between the simulated deep convection and the Africa easterly waves (Sylla et al., 2011). The biases in simulated precipitation for the savannah regions and the central African rainforest area mirror the temperature biases: warm biases coincide with dry biases in central Africa, and cold biases coincide with wet biases in savannah regions. A comparison of the CanESM2driven (FB run) and the ERA-Interim-driven (RP run) simulations (Fig. 1b3) indicates that the bias in simulated precipitation has contributions from both the RCM itself and the GCM-generated boundary conditions. Nevertheless, Nikulin et al. (2012) previously showed for Africa that the model is able to capture the Intertropical Convergence Zone (ITCZ) position and the main features of the seasonal mean rainfall distribution and its annual cycle, and the model biases in precipitation were of similar magnitude to the differences between observational datasets.

The SST forcing is important for African climate. SSTs used in the study domain present warm biases up to $5^{\circ} \mathrm{C}$ for the southeast and equatorial tropical Atlantic, and cold biases for the northern and southern subtropical Atlantic and the Mediterranean Sea (third row, Fig. A1). Such warm biases in the tropical Atlantic, especially in JJA, may partly contribute to the overestimated rainfall in the Guinea coast (Fig. 1b3), and the cold biases in subtropics may link to the underestimated rainfall in the Sahel and southern Africa when comparing to the ERA-Interim-driven simulation (NFB-RP, Fig. 1b3; second row, Fig. A1). The analyses by Rowell (2013) for the global tropics and by LaRow et al. (2014) and $\mathrm{Xu}$ et al. (2014) for tropical subregions suggest that the SST biases in CanESM2 are comparable to other CMIP5 models. To further diagnose the effect of model dynamics on the precipitation bias, we evaluated the low-level circulation and humidity, which play an important role in the moisture transport between ocean and land (Nicholson and Grist, 2003). We compare the simulated circulation and specific humidity at $850 \mathrm{hPa}$ from the NFB run with the regional model against ERA-Interim reanalysis for 1997-2010 (Fig. A2). The simulated patterns of circulation and specific humidity at $850 \mathrm{hPa}$ agree well with the reanalysis: the trade winds over both northern and southern Atlantic, the West African monsoon and the Somali Jet (eastern Africa) are reproduced well by the model. However, there are small biases in wind speed at $850 \mathrm{hPa}$ which generally appear in areas close to the domain 
Future - present day, NFB
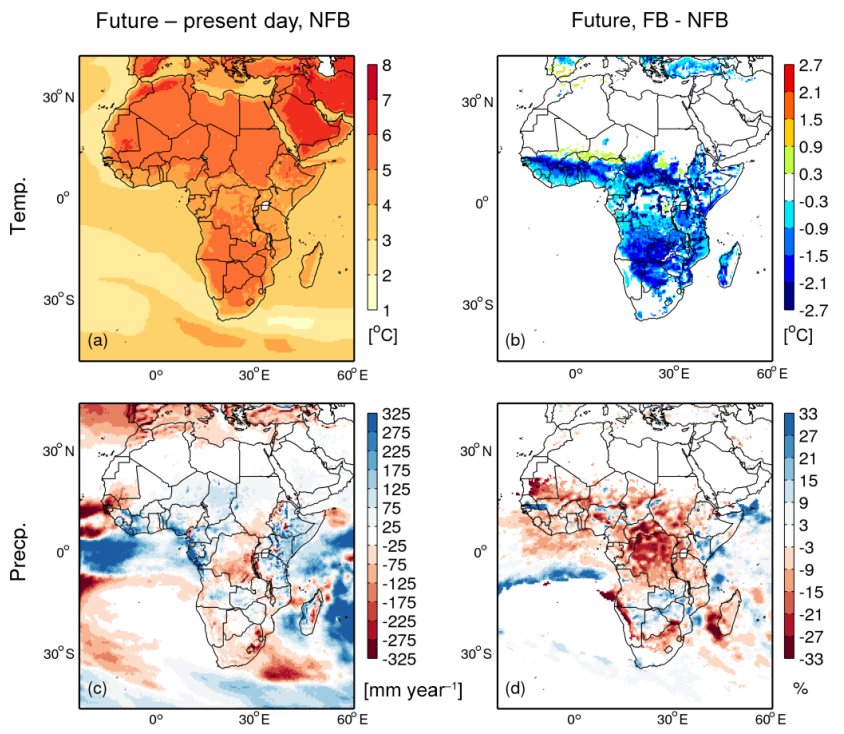

Figure 3. Changes in surface temperature and precipitation due to climate change and vegetation feedback. The calculation of climate change signal and vegetation feedbacks as well as present-day and future periods is defined in Sect. 2.2. For (d), the percentage is calculated as the difference between FB and NFB (vegetation feedback) divided by the present-day level and multiplied by 100 . Grid points with annual mean precipitation $<20 \mathrm{~mm} \mathrm{yr}^{-1}$ are skipped.

boundary and around the African coastal regions. In the case of specific humidity, there are dry biases over the continent. These may be traceable to the different convective schemes used in RCA and ERA-Interim, exhibiting different diurnal cycle of precipitation over Africa (Nikulin et al., 2012).

The simulated seasonality of LAI generally reflects the simulated seasonality of precipitation. A systematic overestimation is apparent for savannahs, as well as a significant underestimation for the central Africa rainforest area. These biases in LAI predominantly reflect the corresponding biases in precipitation (Fig. 2b1-b3 and 2c1-c3). A stronger LAI bias in the savannah is due to the presence of grasses, which are more sensitive to precipitation changes in the model compared to trees.

With present-day forcing, the simulated climate and vegetation patterns and phenology are generally consistent with observations. Some of the biases in the simulated climate are common to many RCMs (Nikulin et al., 2012) and they are apparent for some subregions and seasons in our model. We conclude that the performance is adequate to capture the main details of the African climatology, providing sufficient confidence for the subsequent analysis of regional vegetation-climate interactions under future climate change.

\subsection{Future climate and vegetation change}

In the NFB simulation, most of the African continent is simulated to be $4-6{ }^{\circ} \mathrm{C}$ warmer by the end of the 21 st century

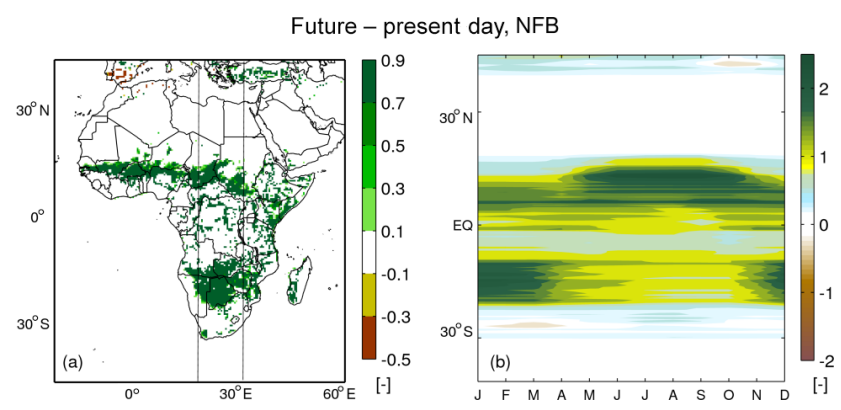

Figure 4. (a) Change in forest fraction and (b) seasonal change in zonal mean forest LAI in the longitude band between 18 and $30^{\circ} \mathrm{E}$ (lines in a), calculated as future minus present day in the FB experiment. Present-day and future periods are defined in Sect. 2.2.

compared with present day (Fig. 3a). The subtropics exhibit a slightly stronger warming than the tropics, and land warming is slightly larger compared to warming of the surrounding ocean surface as simulated by the CanESM2 GCM and represented in the SST forcing fields prescribed from that model. These changes are fairly similar throughout the year, except in northern Africa and the Sahara, where the temperature increase is particularly pronounced in the local dry season (Fig. A3e-h). Precipitation is projected to increase in most parts of the African monsoon area, the western equatorial coastal area and the eastern part of the Horn of Africa (Fig. A4e-h). A slight decrease is projected in the Congo Basin and for the southern part of the continent (Fig. 3c). For areas with a precipitation increase, the increase is mainly confined to the local wet season. The precipitation decrease over central and southern Africa is apparent throughout the year (Fig. A4e-h).

Vegetation feedbacks (FB run) significantly modify the pattern and magnitude of simulated climate change. The effects are largest in low-latitude areas where the surface temperature increase is generally dampened (negative feedback), most notably in savannah areas and to a lesser extent in the equatorial rainforest area (Fig. 3b). The precipitation decrease is enhanced (positive feedback), most notably over the rainforest area (Fig. 3d).

With the effects of climate change and $\mathrm{CO}_{2}$ fertilization, future vegetation growth depicts an enhancement of not only vegetation productivity in general but also tree cover in subtropical savannah areas (Fig. 4a), displacing grasses and reflecting an increase in tree LAI of 0.5-2.4 during the growing season (Fig. 4b). This increase in tree cover reflects a general rise in vegetation productivity driven by rising atmospheric $\mathrm{CO}_{2}$ concentrations on photosynthesis and wateruse efficiency (Long, 1991; Hickler et al., 2008; Keenan et al., 2013). Results from the FB_CC experiment in which $\mathrm{CO}_{2}$ fertilization was disabled reveal that changes in climate drivers alone are simulated to have minor or opposing effects on tree productivity and LAI due to reduced water availability (Fig. A5), and that the changes seen in tree cover and LAI 
in the $\mathrm{FB}$ run hence originate primarily from $\mathrm{CO}_{2}$ fertilization.

Temperature feedbacks tend to be strong in areas of increased tree cover (Figs. 3b, 4a). The cooling effects from vegetation feedbacks are strong (approximately $-2{ }^{\circ} \mathrm{C}$ ) throughout the year, with the most pronounced cooling occurring in the local dry season (Fig. A3i-1), when the newly established tree (with larger root depth than grass) transpires water that is taken up from the deeper soil layer. Transpiration from present-day grass is constrained by the low moisture levels in the top soil layer. As a result, the evaporative cooling effect becomes stronger when forest replaces open land. In the central African rainforest area, where an increase in LAI of about $0.5-1$ is simulated in the FB run compared with the NFB run, vegetation feedbacks on temperature are much smaller in the rainy season but cause cooling in the dry season.

Vegetation feedbacks on precipitation are also pronounced. For the Southern Hemisphere savannah area, a slight increase in precipitation (approximately 10\%, Fig. 3d) was simulated, which is caused by strengthened convective activity (which coincides with enhanced radiation and latent heat fluxes) in the rainy season (DFJ, Fig. A4). This can be considered a local effect of tree LAI increase. However, changes in precipitation are not restricted only to the areas where tree cover increases (Figs. 3d, 4a), which is suggestive of remote effects on tropical precipitation. This is further investigated in the sections below.

\subsection{Vegetation feedback effects on circulation and precipitation}

Vegetation feedbacks on temperature in our simulations operate mainly via an increased surface area for evaporation and a stronger coupling to the atmosphere as tree cover, root depth and LAI increase relative to grasses, most notably in savannah areas, resulting in a shift of the evaporative fraction (ratio of latent heat flux to turbulent heat fluxes) and an increase in surface roughness length. Overall, the turbulent heat fluxes increase, which tends to cool the surface and the lower atmosphere, exceeding the opposing (warming) effects of increased vegetation cover on albedo, thus resulting in an overall cooling effect. Similar behaviour was seen in southern Europe in a previous study with RCA-GUESS (Wramneby et al., 2010).

The variability in precipitation over Africa is greatly influenced by the moisture advection from the ocean to land. Previous studies have noted the influence of Atlantic Walker circulation on central African precipitation, as well as the role of the West African monsoon for precipitation over western Africa (e.g. Nicholson and Grist, 2003; Dezfuli and Nicholson, 2013; Pokam et al., 2014). These circulation systems are associated with thermal contrasts between ocean and land, creating a pressure contrast that tends to promote the movement of moist surface air from the Atlantic over land. We

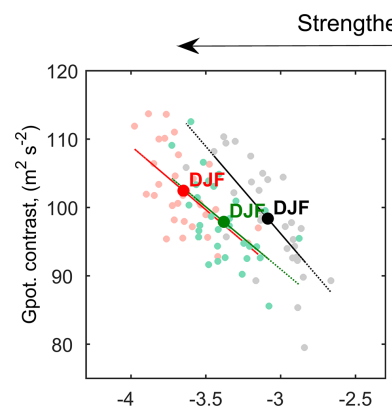

Strengthening temp. contrast
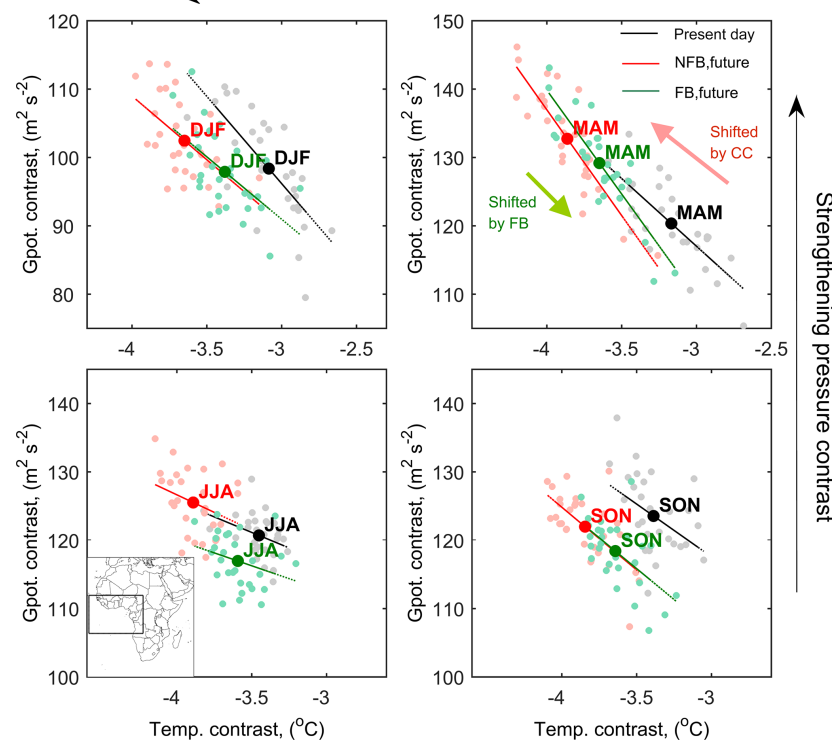

Figure 5. Changes in atmospheric ocean-land temperature contrast $(\nabla T)$ and geopotential contrast $(\nabla \varphi)$, represented by the mean contrast at the three pressure levels 850,925 and $975 \mathrm{hPa}$ (ocean minus land) within the domain $15^{\circ} \mathrm{N}-15^{\circ} \mathrm{S}, 24^{\circ} \mathrm{W}-20^{\circ} \mathrm{E}$ (see the inset in the panel for JJA), for the NFB and FB simulation in the present day and the future period (as defined in Sect. 2.2). Each scatter point represents the relation between $\nabla \varphi$ and $\nabla T$ for the corresponding season of one year, and the slopes represent its sensitivity during the selected periods.

examined the land-ocean thermal contrast $(\nabla T)$ and geopotential contrast $(\nabla \varphi)$ between the equatorial Atlantic and the near-coast African continent for three pressure levels between 850 and $975 \mathrm{hPa}$ in order to characterize the circulation in the lower troposphere. We found that changes in $\nabla T$ and $\nabla \varphi$ are highly interannually anti-correlated for the rainy seasons MAM and SON ( $r=-0.82$ and -0.64 , respectively, Figs. 5; A6). The sensitivity of $\nabla \varphi$ to $\nabla T$, depicted as the slope in Fig. 5, is generally maintained in the future, with a slight decrease in the sensitivity for DJF and a slight increase for MAM.

Under the NFB future simulation, ocean-land contrast becomes larger (the absolute value of $\nabla T$ increases by about $0.5-1{ }^{\circ} \mathrm{C}$, Table A2) as land temperature increases more than the GCM-simulated increase in SSTs provided as forcing to the regional model (Fig. A3). Differential changes in features of the surface and lower atmosphere, such as changes in land-ocean contrasts in boundary layer lapse rate (Joshi et al., 2008) and changes in Bowen ratio over land (Sutton et al., 2007), explain such divergence in temperatures between ocean and land. As a result, except for $\operatorname{SON}, \nabla \varphi$ is generally simulated to increase in the course of the simulation (Fig. A6), with the largest shift occurring in MAM $\left(11.96 \mathrm{~m}^{2} \mathrm{~s}^{-2}\right.$ by the end of $21 \mathrm{st}$ century, Table A2). For SON, $\nabla T$ increases but $\nabla \varphi$ does not, suggesting that the 

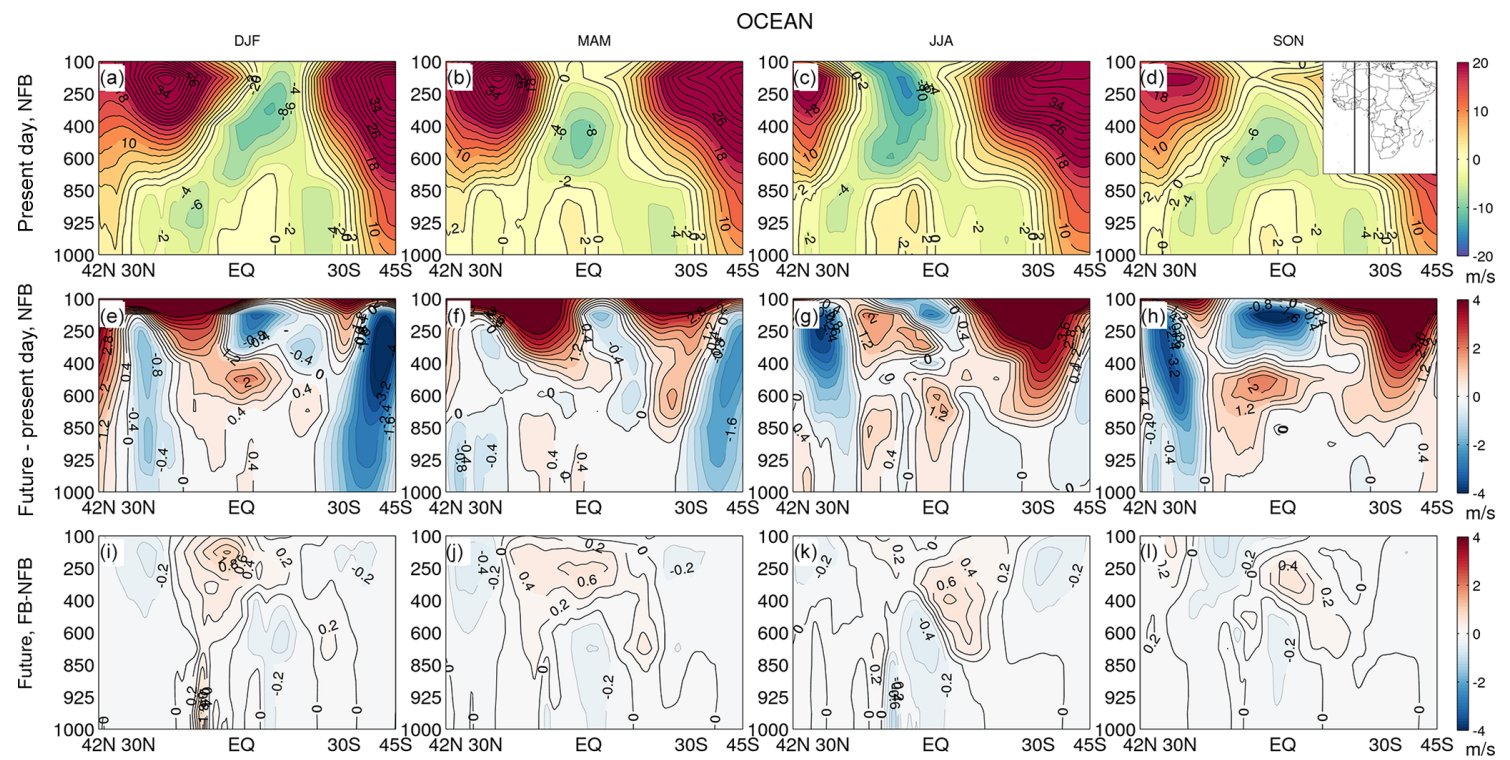

Figure 6. Seasonal mean zonal wind speed in a cross section over adjacent the Atlantic Ocean $\left(0-10^{\circ} \mathrm{E}\right.$; see the inset in $\left.\mathbf{d}\right)$, for present day (first row), changes in future (future minus present day, second row) and the differences between FB and NFB runs in future (FB minus NFB, third row). Units are in $\mathrm{ms}^{-1}$; positive values represent westerlies and negative values represent easterlies. Present-day and future periods are defined in Sect. 2.2. Contour intervals from top row to bottom row are $2,0.4$ and $0.2 \mathrm{~m} \mathrm{~s}^{-1}$, respectively.

trend of $\nabla \varphi$ under climate change is associated with the GCM-derived boundary conditions, despite the strong regional coupling with $\nabla T$ in terms of variability (Fig. A6).

In contrast, the increase in the $\nabla T$ is dampened considerably when incorporating interactive vegetation. The resulting reduction in $\nabla T$ offsets $\nabla \varphi$ uniformly and statistically significantly for all seasons, generally counteracting the climate change effect on $\nabla \varphi$ (Fig. 5, Table A2).

\subsection{Effects on Walker circulation and low-latitude precipitation}

The low-level equatorial westerlies are important to the central African rainfall. They are associated with the lower branch of the Walker cell located near the western equatorial coast of Africa, and they transfer moisture from the adjacent Atlantic to the eastern equatorial coast and the Congo Basin (e.g. Nicholson and Grist, 2003; Schefuß et al., 2005; Cook and Vizy, 2015). These westerlies occur from March to October, being best developed in JJA. They shift northward with the excursion of the ITCZ and under the strong influence of the South Atlantic high-pressure cell (Nicholson and Grist, 2003). This pattern is simulated by RCA-GUESS for the present-day climate (Fig. 6). Via this circulation system, moisture can reach far over the African landmass at around $28^{\circ} \mathrm{E}$, upwell and integrate into the mid-level African easterly jet (AEJ) (Camberlin et al., 2001; Nicholson and Grist, 2003). RCA-GUESS reproduces this pattern with a realistic magnitude (Figs. 6, 7, 8,9) when compared with previ- ous studies based on reanalysis data (Camberlin et al., 2001; Nicholson and Grist, 2003).

In the NFB future simulation, equatorial westerlies are strengthened throughout the year over both ocean (Fig. 6) and land (Fig. 7). Changes in wind speed $(\Delta u)$ can be explained by changes in the low-level pressure contrast between land and ocean (Sect. 3.3), where strengthened $\nabla \varphi$ leads to enhanced $u$, especially for MAM when the zonal pressure contrast prevails (Table A2). Atmospheric specific humidity in the lower troposphere near the Equator also increases by around 10-20\% for MAM and SON, extending from the ocean to inland along the Equator (Figs. $8 \mathrm{~cd}, 9 \mathrm{~cd}$ ). At the same time, changes in future rainfall are apparent along the Equator, with increases over the equatorial coastal or inland areas (Fig. A4), concurrent with stronger moisture inflow to land in the low-level troposphere (Figs. 8cd, 9cd).

Vegetation feedbacks are simulated to weaken the climate change enhancement of the Walker circulation, resulting in a weakening of the equatorial westerlies and counteracting the effects of climate change alone (Fig. 6i-1 and Fig. 7i-l; Fig. 8e, f and Fig. 9e, f). These changes correspond well to changes in low-level ocean-land geopotential contrast $\Delta \nabla \varphi$ with the biggest impact for MAM and SON (Table A2). The weakened Walker circulation is also represented as suppressed vertical uplifting motions over central Africa (Figs. 8f and 9f). Atmospheric specific humidity at $850 \mathrm{hPa}$ is reduced by approximately $7 \%$ due to vegetation feedbacks which are comparable to the contribution of climate change (Fig. 8e, f vs. Fig. 8c, d; Fig. 9e, f vs. Fig. 9c, d). 


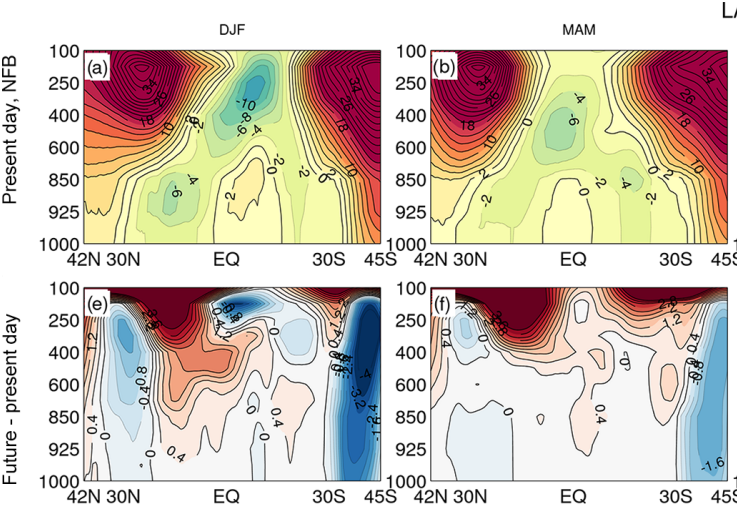

LAND
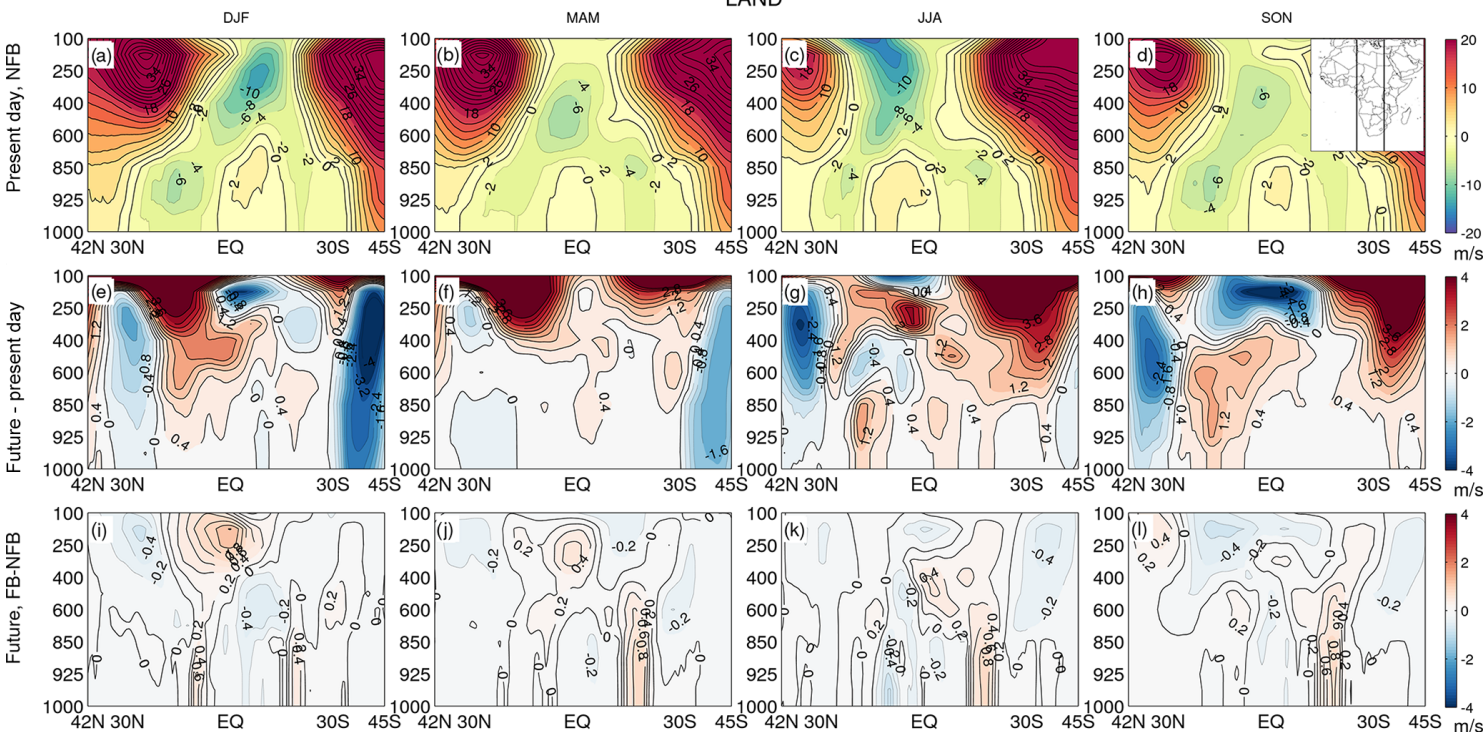

Figure 7. Same as Fig. 6 but for the longitudinal band over land $\left(10-30^{\circ} \mathrm{E}\right.$; see the inset in d).

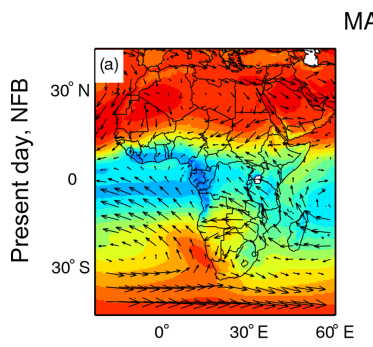

MAM
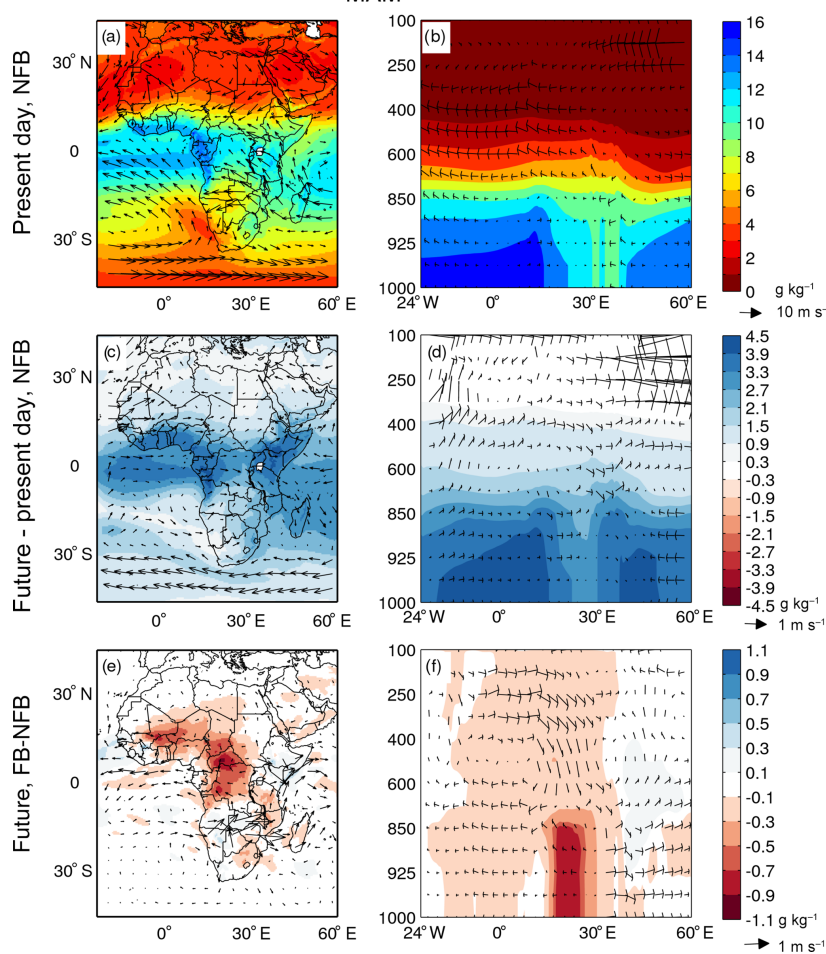

Figure 8. Atmospheric circulation (arrows, $\mathrm{ms}^{-1}$ ) and specific humidity (colour contours, $\mathrm{g} \mathrm{kg}^{-1}$ ) at $850 \mathrm{hPa}$ pressure level for MAM, displayed as (a, c, e) for the entire domain, and $(\mathbf{b}, \mathbf{d}, \mathbf{f})$ as a cross section for a latitude band between $2.5^{\circ} \mathrm{S}$ and $2.5^{\circ} \mathrm{N}$, for present day (top), climate change impacts (middle) and the vegetation feedback (bottom). Definitions for calculation period, climate change signal and vegetation feedbacks are given in Sect. 2.2.
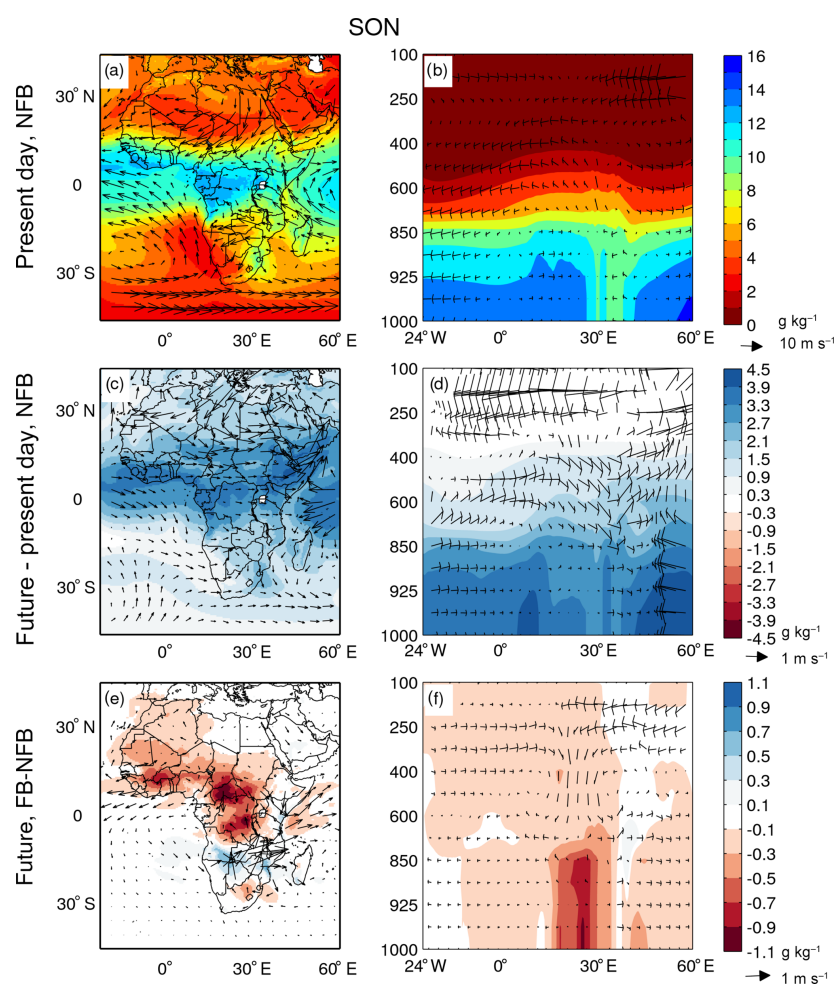

Figure 9. Same as Fig. 8 but for SON.

Analysis of the moisture flux convergence also confirms the impacts of a weakened Walker circulation (Fig. 10) on the hydrological cycle caused by vegetation feedback. Moisture fluxes for most parts of the African continent diverge toward the ocean near the equatorial regions. This divergence is similar for both MAM and SON but the effect is slightly 

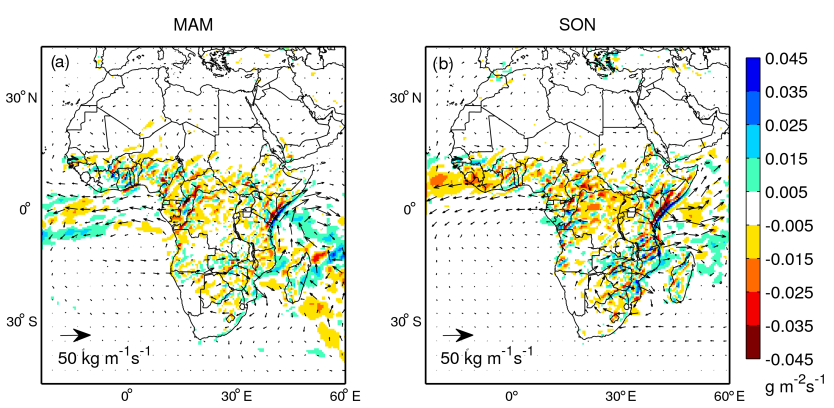

Figure 10. Changes in vertically integrated moisture flux (arrows, $\mathrm{kg} \mathrm{m}^{-1} \mathrm{~s}^{-1}$ ) and moisture flux convergence (colour contours, $\mathrm{g} \mathrm{m}^{-2} \mathrm{~s}^{-1}$ ) caused by vegetation feedback, averaged over the future period (as defined in Sect. 2.2) for (a) MAM and (b) SON.

stronger for SON, which also corresponds to reduced humidity for these areas (Figs. 8e-f; 9e-f).

The changes in precipitation show a distinct spatial and temporal pattern with changes in the rain belt area (defined as a $2 \mathrm{~mm} \mathrm{day}^{-1}$ contour with 10-day smoothing, Fig. 11). Under future conditions, the rain belt, which follows the ITCZ excursion, shifts around $3^{\circ}$ northward during JAS (Fig. 11a). As a result, rainfall intensity increases from May to October, with the most pronounced increase by more than $30 \%$ relative to present-day levels of around $2 \mathrm{~mm} \mathrm{day}^{-1}$ on the margins of the rain belt. The rainy season becomes longer for Sahel ( +9 days) as well as for central Africa ( +1 day). The location of the rain belt for the rest of the year remains unchanged, but there is a pronounced increase in rainfall intensity for the southern African rainy season (about 10\%) and a decrease (about $-10 \%$ ) for the central African rainy seasons.

On top of the non-feedback climate change effect, vegetation feedbacks tend to cause a slight contraction of the rain belt around the Equator, and they impose a primarily counteractive effect on rainfall intensity compared to the climate change alone simulation (NFB). For central Africa, the considerable decrease in rainfall intensity in the dry season leads to a slight equatorward shrinking of the rain belt (approximately $2^{\circ}$ ) and a shorter rainy season (on average 10 days, represented as a 4-day postponed onset and a 6-day earlier end). For southern Africa, strengthened convective precipitation results in a longer rainy season by on average 6 days. There is no pronounced effect for the Sahel regions except for some sparse changes over time and in some areas. To investigate the effects on ITCZ location, we analysed the position of the intertropical front (ITF) with a meridional wind criterion (Sultan and Janicot, 2003) by examining the location of maximum vertical uplifting wind speed at $850 \mathrm{hPa}$ over Sahel in July and over southern Africa in January. However, we did not find pronounced effects for ITF (not shown) suggesting that changes in the rain belt location for central Africa are mainly caused by changes in precipitation intensity rather than by changes in meridional circulation.
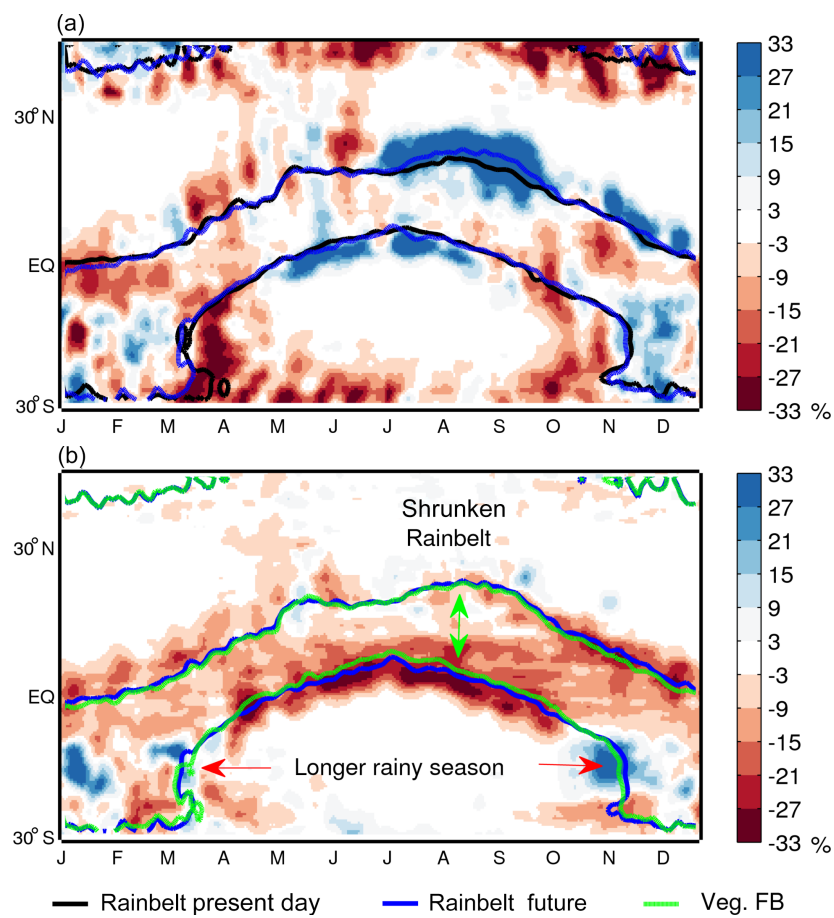

Figure 11. Daily changes in precipitation averaged over the longitude band $18-30^{\circ} \mathrm{E}$, represented as relative changes in daily precipitation intensity (shading, \%) and rain belt location (contour) due to (a) climate change and (b) vegetation feedback for future. The rain belt location is defined as a $2 \mathrm{~mm} \mathrm{day}^{-1}$ contour. Ten-day running mean is applied for daily values.

\section{Discussion}

\subsection{Related tenets of regional Earth system modelling}

We investigated the coupled dynamics of climate and vegetation over Africa under a future climate change scenario, applying a regional-scale ESM that dynamically couples a dynamic representation of vegetation structure, composition and distribution to a physical climate model at a comparatively high grid resolution. Uniquely among existing studies of climate dynamics for Africa, this enabled us to isolate the regional biophysical feedbacks, which are usually not easy to disentangle in a global application in which the effects of changes in carbon cycle and large-scale circulation tend to compound the biophysical effects.

In comparison with global ESMs, the added value from the regional ESMs lies in the enhanced resolution obtained in a regional setup as presented in this study, allowing for a more detailed representation of local surface features such as topography, land use, vegetation change, and consequently possible related feedbacks, and also enhancing the model's ability to capture climatic variability and extreme climatic events (Giorgi, 1995; Rummukainen, 2010, 2016). Improvements in the representation of local processes may be expected to result in improved larger-scale features (e.g. sea 
level pressure, circulation patterns) (Diffenbaugh et al., 2005; Feser, 2006). For example, Kjellström et al. (2005) found that reduced bias in surface air temperature - largely determined by local energy balance - resulted in a better representation of interannual variability in mean sea level pressure and circulation patterns and improved the simulation of precipitation.

\subsection{African vegetation patterns and change}

Vegetation dynamics are critically important in modulating the evolution of the 21 st century climate in our study. Land use and grazing (Sankaran et al., 2005; Bondeau et al., 2007; Lindeskog et al., 2013), which were not included in our study, represent additional potentially important drivers of land surface changes. The historical vegetation state is also relevant for future simulations, due to legacy effects lasting decades or even centuries (Moncrieff et al., 2014) and their influences on climate-vegetation equilibria (Claussen, 1998; Wang and Eltahir, 2000). While our model exhibited a degree of bias in simulated vegetation under the present climate, the overall distribution of the major vegetation types of the continent (forest, savannah and grassland) was broadly correct. Arguably, vegetation type is a more important determinant of climate-vegetation equilibrium than structural parameters of a given type, such as LAI (Claussen, 1994; Wang and Eltahir, 2000).

Previous experimental (Kgope et al., 2010) and modelling (Sitch et al., 2008; Moncrieff et al., 2014) studies highlight the potential importance of physiological effects of atmospheric $\mathrm{CO}_{2}$ concentrations on the productivity and water use efficiency of vegetation, particularly in low-latitude and water-limited ecosystem types. Shrub encroachment and woody thickening has been observed in water-limited areas including Sahel in recent decades, coinciding with rising $\mathrm{CO}_{2}$ concentrations (e.g. Liu et al., 2015). In our results, the simulated vegetation dynamics are consistent with these trends, presenting a trajectory of increased woody plant dominance (not shown), and a similar future vegetation pattern (Fig. 4) as in previous modelling studies (e.g. Sitch et al., 2008; Moncrieff et al., 2014). The vegetation changes simulated by our model under future climate forcing are large compared to the bias noted in the representation of presentday vegetation state. This provides some confidence that the simulated future vegetation is not critically dependent on these biases and, in turn, that the emergent mechanisms of vegetation-climate interaction and their consequences for circulation and precipitation trends suggested by our study are robust.

\subsection{Vegetation feedbacks and land-ocean temperature contrasts}

The land-ocean contrast is an important driver of continental precipitation, as it determines the transport of moisture from ocean to land (e.g. Giannini et al., 2003, 2005; Fasullo, 2010; Boer, 2011; Lambert et al., 2011). The positive trend in Sahel rainfall over recent decades is a good example of linking moisture transport to land-ocean contrast, where changes in SSTs over adjacent tropical oceans around Africa are key to the fragile balance that defines the regional circulation system (Camberlin et al., 2001; Rowell, 2001; Giannini et al., 2003). Land surface feedback is found to modify the interannual to interdecadal climate variability in this region by vegetation-induced albedo or evapotranspiration effects (Zeng et al., 1999; Wang et al., 2004). In our study, the SSTs were prescribed from GCM-generated data; therefore, the altered land-ocean thermal contrast between simulations with and without feedback originated solely from the changes in land surface temperature, in turn attributable to vegetation dynamics. Although this represents a land-forced mechanism in contrast to an ocean-forced one inferred in other studies (e.g. Giannini et al., 2003; Tokinaga et al., 2012), the mechanisms are similar. Wind speed and land-ocean temperature contrast are reduced by approximately by $0.2 \mathrm{~m} \mathrm{~s}^{-1}$ and $0.2^{\circ} \mathrm{C}$, respectively, when vegetation feedbacks are enabled in our study (Fig. 5 and Table A2); these are comparable to the changes simulated in other studies for the Sahel (approximately $0.2-0.5 \mathrm{~m} \mathrm{~s}^{-1}$ per $0.2{ }^{\circ} \mathrm{C}$, Giannini et al., 2005) and for the Pacific Ocean (approximately $0.3 \mathrm{~m} \mathrm{~s}^{-1}$ per $0.3^{\circ} \mathrm{C}$; Tokinaga et al., 2012). However, the relative importance of such changes may differ for local climate systems: the lower branch of the Walker cell over the eastern tropical Atlantic Ocean, which we have focused on in this study, may be in a fragile balance and is more vulnerable to changes in thermal contrasts (equatorial westerlies slowed down by approximately $0.2 \mathrm{~m} \mathrm{~s}^{-1}$ from less than $2 \mathrm{~m} \mathrm{~s}^{-1}$ of the presentday wind speed in rainy seasons, Table A2) compared to the stronger monsoonal circulation for Sahel and the Walker cell over the equatorial Pacific Ocean ( $>5 \mathrm{~m}$ per second wind speed in their peak months; Young, 1999). Our results indicate that even a small disturbance of the eastern tropical Atlantic circulation cell may produce profound impacts (larger relative reduction in precipitation compared with the studies by Giannini et al., 2005, and Tokinaga et al., 2012).

Similar to the local effects over semiarid region identified in a previous vegetation feedback study focusing on an African sub-domain (Yu et al., 2015), in which vegetation feedback increases local precipitation, our study in advance presents a remote effect induced by vegetation feedback over the African wet tropics that may not be easy to capture in a smaller simulation domain. A larger domain including sufficient adjacent ocean could enhance land-ocean interaction through changes in regional circulation and allow regional teleconnection features to develop, e.g. the influences of the tropical Atlantic on rainfall in the Guinea coast and central Africa (Camberlin et al., 2001; Nicholson and Grist, 2003), and link between the Mediterranean Sea and Sahelian rainfall (Rayner et al., 2003). Despite biases in the present-day precipitation and vegetation state (LAI) for some regions, 
our model was able to reproduce the present-day land cover type, and the simulated present-day climate is close to previous study (Nikulin et al., 2012) using the same physical sub-model with observed land cover type. Under future climate change, vegetation-induced changes in circulation, and thus a substantial change in moisture transport and precipitation, are mainly triggered by changes in land cover type (Fig. 4a); therefore, we argue that the influences from biases in initial conditions on such mechanism found in this study should be limited. Our study used prescribed SST forcing from a GCM and could thus not account for additional or opposing feedbacks mediated by ocean dynamics. However, as the ocean heat capacity is relatively large and variation in land-ocean thermal contrast can be greatly buffered by ocean heat uptake (Lambert and Chiang, 2007), we suggest that results should not change fundamentally if a dynamic ocean component was introduced to the model.

\section{Conclusion and outlook}

We investigated the potential role of vegetation-mediated biophysical feedbacks on climate change projections for Africa in the 21 st century. In current savannah regions, enhanced forest growth results in a strong evaporative cooling effect. We also identify alterations in the large-scale circulation induced by savannah vegetation change, resulting in remote effects and modulation of tropical rainfall patterns over Africa, favouring savannah ecosystems at the expense of equatorial rainforest. Our results point to the potential importance of vegetation-atmosphere interactions for regional climate dynamics and trends and motivate the incorporation of vegetation dynamics and land-atmosphere biophysical coupling in regional models. This has become the standard in global climate modelling but remains rare in regional climate modelling.
Future work can include detailed studies on the role of vegetation feedbacks in the regional climate projections with respect to shorter-term dynamics such as climate variability and extreme events, which may have crucial implications for landscape processes such as wildfire. Regional and global biogeochemical feedbacks on future climate change may be triggered by regional biophysical feedbacks, with implications for regional climatic trends, variability and seasonality under future greenhouse forcing (Zhang et al., 2014). Impacts on the carbon balance of semi-arid ecosystem like savannahs, known to respond sensitively to variations in rainfall (Ahlström et al., 2015), may be particularly relevant to address for Africa. The development of regional ESMs to account for the impacts of land use interventions such as afforestation and reforestation, as well as forest clearing, grazing and fire management, may be a valuable next step, enabling land surface-atmosphere interaction studies linked to socioeconomic scenarios and climate change mitigation strategies.

\section{Data availability}

The CRU TS 3.23 global historical datasets (Harris et al., 2014) are available at https://crudata.uea.ac.uk/cru/data/hrg/ cru_ts_3.23/cruts.1506241137.v3.23/ The GPCP datasets (Huffman et al., 2001) are available at http://precip.gsfc. nasa.gov/gpcp_daily_comb.html The GIMMS-AVHRR and MODIS-based LAI3g product (Zhu et al., 2013) can be accessed through http://cliveg.bu.edu/modismisr/lai3g-fpar3g. html. The ERA-Interim datasets (Berrisford et al., 2009) are available at http://apps.ecmwf.int/datasets/. The HadISSTv1.1 datasets (Rayner et al., 2003) are available at http://www.metoffice.gov.uk/hadobs/hadisst/. To obtain the simulation datasets of this study, please contact minchao.wu@nateko.lu.se. 


\section{Appendix A: Description of the coupling between RCA and LPJ-GUESS}

In RCA-GUESS, the LSS in RCA is coupled with LPJGUESS, which feeds back vegetation properties to RCA. RCA provides net downward shortwave radiation, air temperature, precipitation to LPJ-GUESS. In return, LPJGUESS provides daily updated LAI and the annually updated tile sizes (determined from the simulated maximum growing season LAI summed across tree and herbaceous PFTs in the previous year; Smith et al., 2011). In the forest tile in RCA, vegetation cover in this tile is estimated as the foliar projective cover (FPC) using Beer's law:

$A_{\text {tree }}=1.0-\exp \left(-0.5 \cdot \mathrm{LAI}_{\text {tree }}\right)$,

where $\mathrm{LAI}_{\text {tree }}$ is the aggregated LAI of woody species, simulated by LPJ-GUESS in its forest tile in which vegetation is assumed to comprise trees and understorey herbaceous vegetation. The natural vegetated faction of the open land tile was calculated similarly:

$A_{\text {grass }}=1.0-\exp \left(-0.5 \cdot \mathrm{LAI}_{\text {grass }}\right)$,

where $\mathrm{LAI}_{\text {grass }}$ is the summed LAI of the simulated herbaceous PFTs from the herbaceous tile of LPJ-GUESS in which only herbaceous vegetation is allowed to grow. The relative covers of the forest and open land tiles affect surface albedo, which is a weighted average of prescribed albedo constants for forest, open land, and bare soil and controls the absorption of surface incoming solar radiation and therefore influences surface energy balance and temperature.
The turbulent heat fluxes are influenced by the properties of each tile, such as surface roughness and surface resistance, which partly depend on vegetation properties provided by LPJ-GUESS. The vegetation surface resistance controls vegetation transpiration and bare soil evaporation for latent heat flux calculation. It scales with LAI and varies between the different types of vegetation and affected by the incoming photosynthetically active radiation, soil-water stress, vapour pressure deficit, air temperature and soil temperature. The aerodynamic resistance controls both latent heat flux and sensible heat flux and is influenced by surface roughness length distinguished from open land and forest. The total heat fluxes and heat transfer determine the time evolution of the surface temperature and thus the thermodynamics in the lower boundary layer. More details about the LSS are given in Samuelsson et al. (2006), and the description of its coupling to the vegetation sub-model is provided by Smith et al. (2011).

Table A1. Characteristics of the plant functional types (PFTs) used in the vegetation sub-model LPJ-GUESS.

\begin{tabular}{lllllllll}
\hline Characteristics & $\mathrm{NE}$ & $\mathrm{BE}$ & $\mathrm{TrBE}$ & $\mathrm{TrBR}$ & $\mathrm{TBS}$ & $\mathrm{IBS}$ & $\mathrm{C} 3 \mathrm{G}$ & $\mathrm{C} 4 \mathrm{G}$ \\
\hline Leaf phenology & $\mathrm{a}$ & $\mathrm{E}$ & $\mathrm{E}$ & $\mathrm{D}$ & $\mathrm{D}$ & $\mathrm{D}$ & $\mathrm{R}$ & $\mathrm{R}$ \\
Drought tolerance & $\mathrm{E}$ & low & low & low & low & low & very low very low \\
Shade tolerance & high & high & high & low & high & low & low & Low \\
Optimal temperature range for photosynthesis $\left({ }^{\circ} \mathrm{C}\right)$ & $10-25$ & $15-35$ & $25-30$ & $25-30$ & $15-25$ & $10-25$ & $10-30$ & $20-45$ \\
Min $T_{\mathrm{c}}$ for survival $\left({ }^{\circ} \mathrm{C}\right)^{\mathrm{b}}$ & - & 1.7 & 15.5 & 15.5 & -18 & - & - & 15.5 \\
\hline
\end{tabular}

Notes: NE, needleleaved evergreen tree; BE, broadleaved evergreen tree; TrBE, tropical broadleaved evergreen tree; TrBR, tropical broadleaved raingreen tree; TBS, shade-tolerant broadleaved summergreen tree; IBS, shade-intolerant broadleaved summergreen tree; $\mathrm{C} 3 \mathrm{G}, \mathrm{C} 3$ grass or herb; C4G, C4 grass or herb;

${ }^{a} \mathrm{E}$, evergreen; $\mathrm{D}$, deciduous; $\mathrm{R}$, raingreen.

${ }^{\mathrm{b}} T_{\mathrm{c}}$ : mean temperature $\left({ }^{\circ} \mathrm{C}\right)$ of coldest month of year. 

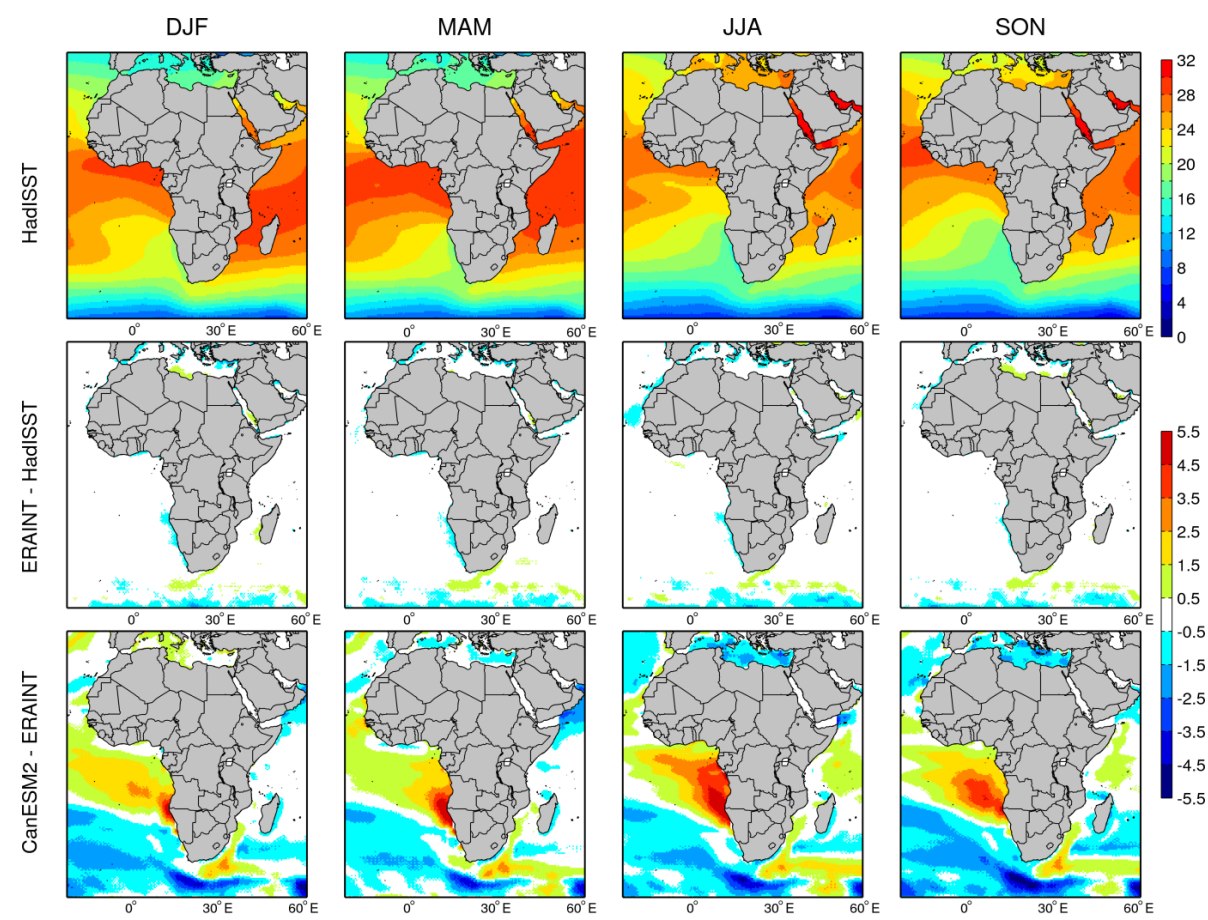

Figure A1. Seasonal sea-surface temperature $\left({ }^{\circ} \mathrm{C}\right)$ from the observational SST dataset HadISSTv1.1 (first row; Rayner et al., 2003), and the biases of ERA-Interim (second row) and CanESM2 (third row) against the observed biases for the period 1997-2010.

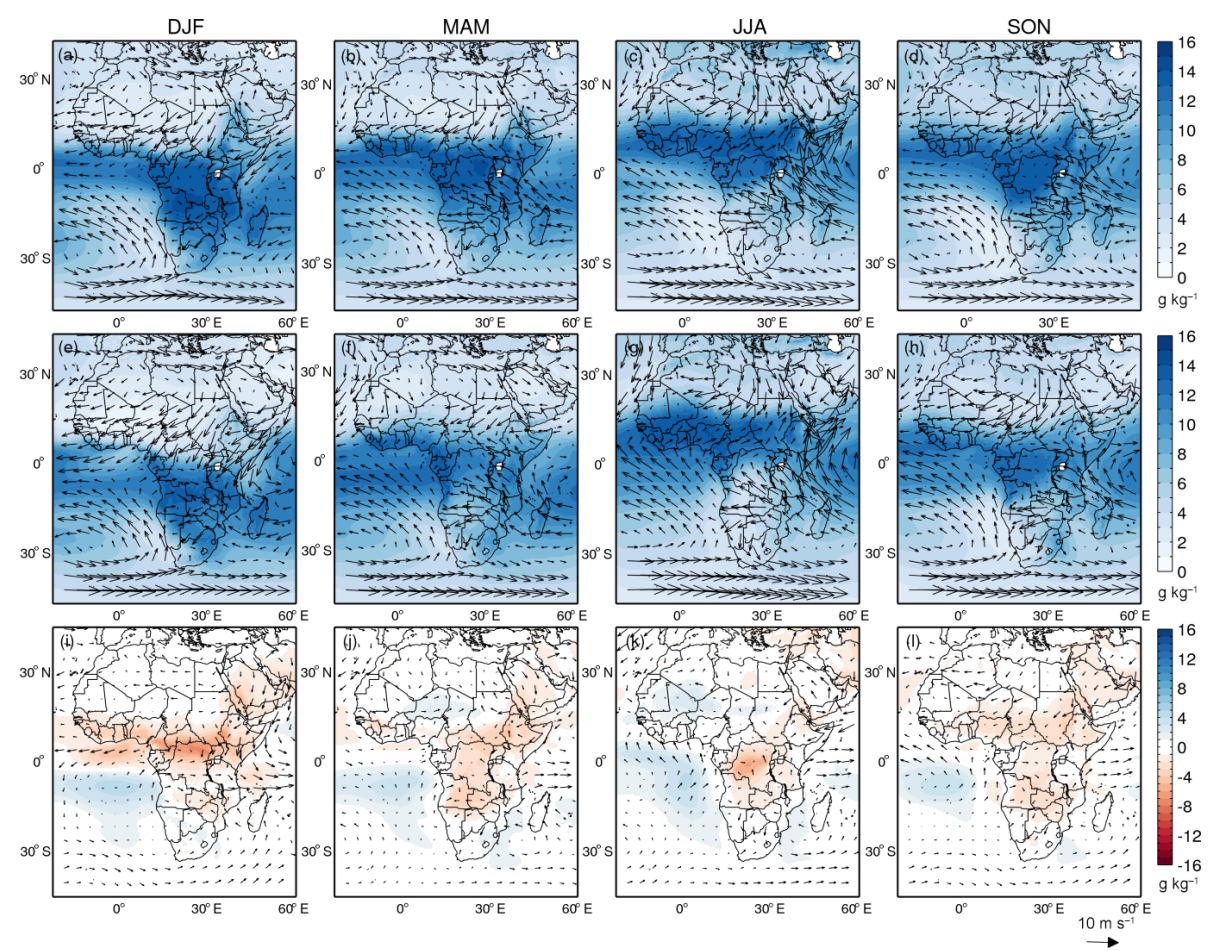

Figure A2. Seasonal atmospheric circulation (arrows, $\mathrm{m} \mathrm{s}^{-1}$ ) and specific humidity (colour contours, $\mathrm{g} \mathrm{kg}^{-1}$ ) at $850 \mathrm{hPa}$ pressure level from ERA-Interim (first row), the NFB run (second row), and their differences (third row, NFB minus ERA-Interim) for the period 1997-2010. 


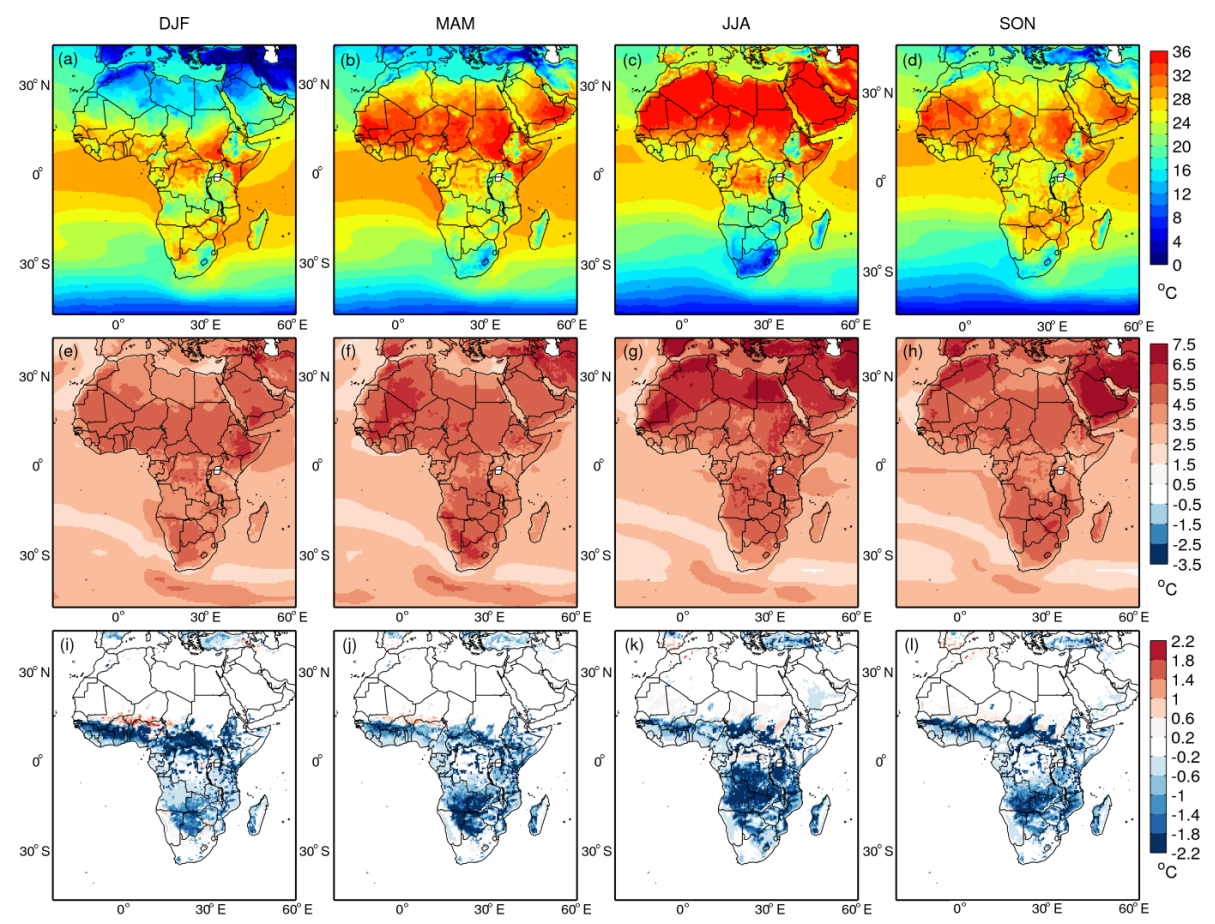

Figure A3. Simulated seasonal surface temperature for present day (a-d), for changes in future in the NFB experiment (e-h, future minus present day), and for changes from vegetation feedback in future (i-l, FB minus NFB for future). Definitions for calculation period, climate change signal and vegetation feedbacks are given in Sect. 2.2.

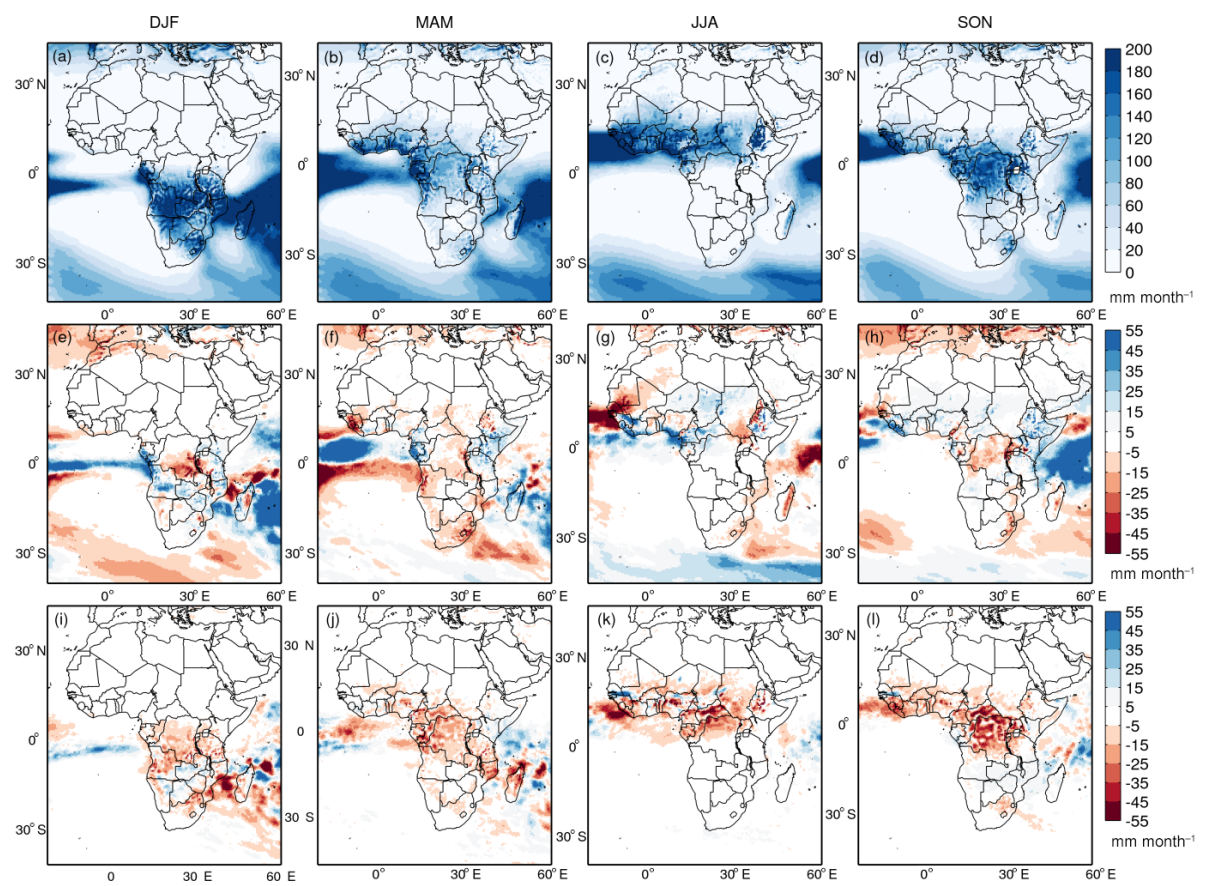

Figure A4. Similar to Fig. A3 but for precipitation. 


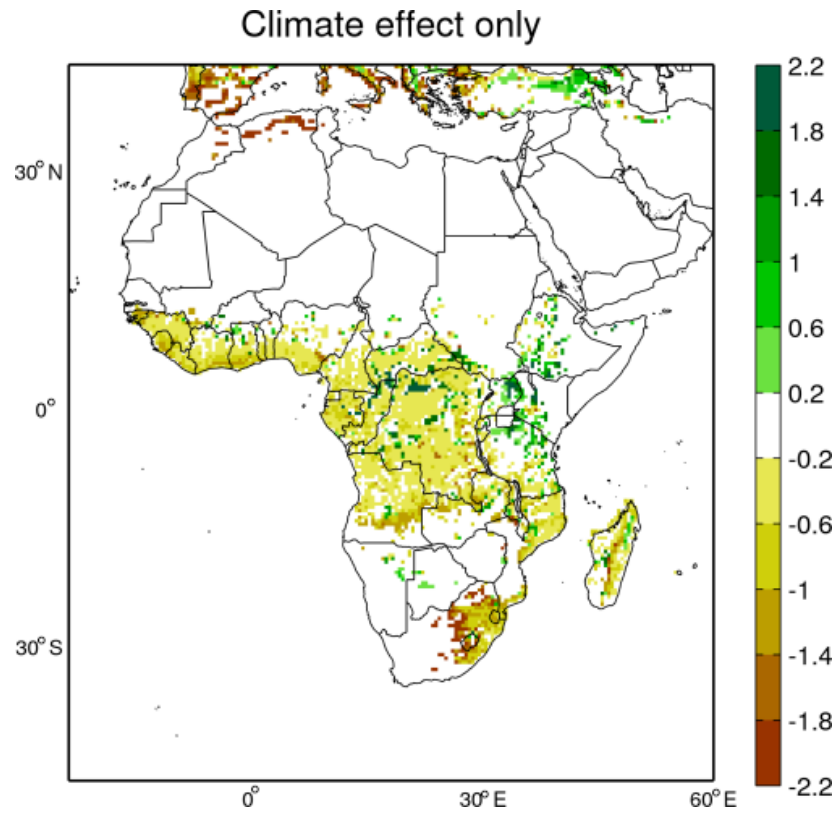

Figure A5. Changes in forest tile LAI from the period 1991-2010 to the period 2081-2100 in the FB_CC experiment.
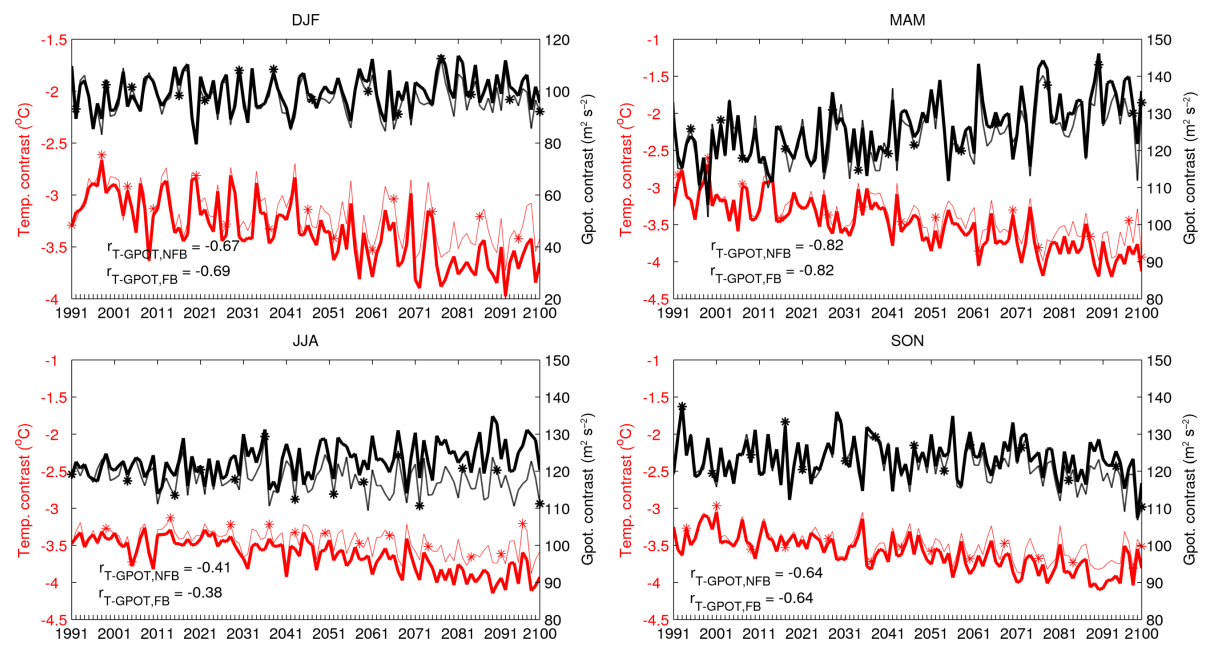

Figure A6. Annual changes in atmospheric ocean-land temperature contrast $(\nabla T)$ and geopotential contrast $(\nabla \varphi)$ in time series for four seasons, represented by the mean contrast at the three pressure levels 850,925 and $975 \mathrm{hPa}$ (ocean minus land) within the domain $15^{\circ} \mathrm{N}-$ $15^{\circ} \mathrm{S}, 24^{\circ} \mathrm{W}-20^{\circ} \mathrm{E}$ (see the inset in the panel for JJA in Fig. 5). Correlation coefficient $(r)$ between atmospheric temperature contrast $(\nabla T)$ and geopotential contrast $(\nabla \varphi)$ are computed based on the de-trended annual time-series values for both FB (thick lines) and NFB (thin lines with asterisks) simulations. Changes between FB and NFB are significant at $95 \%$ confidence level for the whole time period. Note the different $y$ axis for DJF. 
Table A2. Atmospheric temperature contrast, geopotential contrast and westerly wind speed for the present-day state and contributions from climate change (CC subscript) and vegetation feedbacks (FB subscript). Standard deviation is in parentheses.

\begin{tabular}{|c|c|c|c|c|c|c|c|}
\hline & \multicolumn{2}{|r|}{ DJF } & \multicolumn{2}{|r|}{ MAM } & \multicolumn{2}{|r|}{ JJA } & SON \\
\hline$\nabla T_{\text {present day }}\left({ }^{\circ} \mathrm{C}\right)^{\mathrm{a}}$ & -3.00 & $6(0.30)$ & -3.15 & $5(0.34)$ & -3.47 & $7(0.22)$ & $-3.37(0.24)$ \\
\hline$\Delta \nabla T_{\mathrm{CC}}\left({ }^{\circ} \mathrm{C}\right)^{\mathrm{a}}$ & & $-0.59 *$ & & $-0.73^{*}$ & & $-0.45^{*}$ & $-0.47^{*}$ \\
\hline$\Delta \nabla T_{\mathrm{FB}}\left({ }^{\circ} \mathrm{C}\right)^{\mathrm{a}}$ & & $0.29^{*}$ & & $0.23^{*}$ & & $0.31^{*}$ & $0.22 *$ \\
\hline$\nabla \varphi_{\text {present day }}\left(\mathrm{m}^{2} \mathrm{~s}^{-2}\right)^{\mathrm{a}}$ & 98.14 & $+(5.92)$ & 120.8 & $6(7.03)$ & 120.9 & $4(3.83)$ & $124.08(4.58)$ \\
\hline$\Delta \nabla \varphi_{\mathrm{CC}}\left(\mathrm{m}^{2} \mathrm{~s}^{-2}\right)^{\mathrm{a}}$ & & 3.94 & & $11.96^{*}$ & & $4.73^{*}$ & -3.32 \\
\hline$\Delta \nabla \varphi_{\mathrm{FB}}\left(\mathrm{m}^{2} \mathrm{~s}^{-2}\right)^{\mathrm{a}}$ & & $-4.93^{*}$ & & $-3.86^{*}$ & & $-8.96^{*}$ & $-3.92 *$ \\
\hline$u_{\text {zonal,present day }}\left(\mathrm{m} \mathrm{s}^{-1}\right)^{\mathrm{b}}$ & 0.01 & $(0.27)$ & 1.47 & $(0.32)$ & 0.87 & $(0.37)$ & $(0.31)$ \\
\hline$\Delta u_{\text {zonal,CC }}\left(\mathrm{m} \mathrm{s}^{-1}\right)^{\mathrm{b}}$ & & $0.35^{*}$ & & $0.32^{*}$ & & $0.68^{*}$ & $0.17^{*}$ \\
\hline$\Delta u_{\text {zonal,FB }}\left(\mathrm{m} \mathrm{s}^{-1}\right)^{\mathrm{b}}$ & & -0.00 & & $-0.21^{*}$ & & $-0.28^{*}$ & $-0.16^{*}$ \\
\hline
\end{tabular}

Note: ${ }^{\text {a }}$ calculations are the same as Fig. 5 .

$\mathrm{b} u_{\text {zonal }}$ is the averaged zonal wind speed for the pressure levels 850,925 and $975 \mathrm{hPa}$ between 3.5 and $6.5^{\circ} \mathrm{N}$ and 0 and

$10^{\circ} \mathrm{E}$; the positive represents westerly and the negative represents easterly.

* Changes are significant at the $95 \%$ confidence level using the Mann-Whitney $U$ test (Hollander and Wolfe, 1999). 
Acknowledgements. This study is a contribution to the strategic research areas Modelling the Regional and Global Earth System (MERGE) and Biodiversity and Ecosystem Services in a Changing Climate (BECC). M. Wu would like to thank Paul Miller and Grigory Nikulin for their helpful discussions and comments on this work. The model simulations were performed at the National Supercomputer Centre (NSC) in Linköping, Sweden.

Edited by: M. Claussen

Reviewed by: two anonymous referees

\section{References}

Ahlström, A., Raupach, M. R., Schurgers, G., Smith, B., Arneth, A., Jung, M., Reichstein, M., Canadell, J. G., Friedlingstein, P., and Jain, A. K.: The dominant role of semi-arid ecosystems in the trend and variability of the land $\mathrm{CO}_{2}$ sink, Science, 348, 895899, 2015.

Alo, C. A. and Wang, G.: Role of dynamic vegetation in regional climate predictions over western Africa, Clim. Dynam., 35, 907922, 2010.

Anav, A., Friedlingstein, P., Kidston, M., Bopp, L., Ciais, P., Cox, P., Jones, C., Jung, M., Myneni, R., and Zhu, Z.: Evaluating the Land and Ocean Components of the Global Carbon Cycle in the CMIP5 Earth System Models, J. Climate, 26, 6801-6843, doi:10.1175/jcli-d-12-00417.1, 2013.

Arora, V., Scinocca, J., Boer, G., Christian, J., Denman, K., Flato, G., Kharin, V., Lee, W., and Merryfield, W.: Carbon emission limits required to satisfy future representative concentration pathways of greenhouse gases, Geophys. Res. Lett., 38, doi:10.1029/2010GL046270, 2011.

Avissar, R. and Werth, D.: Global hydroclimatological teleconnections resulting from tropical deforestation, J. Hydrometeorol., 6, 134-145, 2005.

Berrisford, P., Dee, D., Fielding, K., Fuentes, M., Kallberg, P., Kobayashi, S., and Uppala, S.: The ERA-Interim Archive, ERA Report Series, 1. Technical Report, European Centre for Medium-Range Weather Forecasts, Shinfield Park, Reading, 16 pp., 2009. (Datasets: ERA-Interim (January 1979-present), retrieved from http://apps.ecmwf.int/datasets/, last access: May 2016)

Boer, G.: The ratio of land to ocean temperature change under global warming, Clim. Dynam., 37, 2253-2270, 2011.

Bonan, G. B.: Forests and climate change: forcings, feedbacks, and the climate benefits of forests, Science, 320, 1444-1449, 2008.

Bondeau, A., Smith, P. C., Zaehle, S., Schaphoff, S., Lucht, W., Cramer, W., Gerten, D., Lotze-Campen, H., Müller, C., and Reichstein, M.: Modelling the role of agriculture for the 20th century global terrestrial carbon balance, Glob. Change Biol., 13, 679-706, 2007.

Brovkin, V., Claussen, M., Driesschaert, E., Fichefet, T., Kicklighter, D., Loutre, M.-F., Matthews, H., Ramankutty, N., Schaeffer, M., and Sokolov, A.: Biogeophysical effects of historical land cover changes simulated by six Earth system models of intermediate complexity, Clim. Dynam., 26, 587-600, 2006.

Camberlin, P., Janicot, S., and Poccard, I.: Seasonality and atmospheric dynamics of the teleconnection between African rainfall and tropical sea-surface temperature: Atlantic vs. ENSO, Int. J. Climatol., 21, 973-1005, 2001.
Charney, J. G.: Dynamics of deserts and drought in the Sahel, Q. J. Roy. Meteorol. Soc., 101, 193-202, 1975.

Claussen, M.: On coupling global biome models with climate models, Climate Res., 4, 203-221, 1994.

Claussen, M.: Modeling bio-geophysical feedback in the African and Indian monsoon region, Clim. Dynam., 13, 247-257, 1997.

Claussen, M.: On multiple solutions of the atmosphere-vegetation system in present-day climate, Glob. Change Biol., 4, 549-559, 1998.

Claussen, M. and Gayler, V.: The Greening of the Sahara during the Mid-Holocene: Results of an Interactive AtmosphereBiome Model, Glob. Ecol. Biogeogr. Lett., 6, 369-377, doi:10.2307/2997337, 1977.

Cook, K. H. and Vizy, E. K.: The Congo Basin Walker circulation: dynamics and connections to precipitation, Clim. Dynam., 1-21, doi:10.1007/s00382-015-2864-y, 2015.

Dezfuli, A. K. and Nicholson, S. E.: The relationship of rainfall variability in western equatorial Africa to the tropical oceans and atmospheric circulation. Part II: The boreal autumn, J. Climate, 26, 66-84, 2013.

Diffenbaugh, N. S., Pal, J. S., Trapp, R. J., and Giorgi, F.: Finescale processes regulate the response of extreme events to global climate change, P. Natl. Acad. Sci. USA, 102, 15774-15778, doi:10.1073/pnas.0506042102, 2005.

Döscher, R., Wyser, K., Meier, H. M., Qian, M., and Redler, R.: Quantifying Arctic contributions to climate predictability in a regional coupled ocean-ice-atmosphere model, Clim. Dynam., 34, 1157-1176, 2010.

Eklundh, L. and Olsson, L.: Vegetation index trends for the African Sahel 1982-1999, Geophys. Res. Lett., 30, doi:10.1029/2002GL016772, 2003.

Eltahir, E. A.: Role of vegetation in sustaining large-scale atmospheric circulations in the tropics, J. GEophys. Res.-All Series, 101, 4255-4268, 1996.

Fasullo, J. T.: Robust Land-Ocean Contrasts in Energy and Water Cycle Feedbacks*, J. Climate, 23, 4677-4693, 2010.

Feser, F.: Enhanced detectability of added value in limited-area model results separated into different spatial scales, Mon. Weather Rev., 134, 2180-2190, 2006.

Giannini, A., Saravanan, R., and Chang, P.: Oceanic forcing of Sahel rainfall on interannual to interdecadal time scales, Science, 302, 1027-1030, 2003.

Giannini, A., Saravanan, R., and Chang, P.: Dynamics of the boreal summer African monsoon in the NSIPP1 atmospheric model, Clim. Dynam., 25, 517-535, 2005.

Giorgi, F.: Perspectives for regional earth system modeling, Global Planet. Change, 10, 23-42, 1995.

Giorgi, F., Jones, C., and Asrar, G. R.: Addressing climate information needs at the regional level: the CORDEX framework, World Meteorological Organization (WMO) Bulletin, 58, 175, 2009.

Harris, I., Jones, P. D., Osborn, T. J., and Lister, D. H.: Updated high-resolution grids of monthly climatic observations - the CRU TS3.10 Dataset, Int. J. Climatol., 34, 623-642, doi:10.1002/joc.3711, 2014. (Datasets: CRU TS3.23: Climatic Research Unit (CRU) Time-Series (TS) Version 3.23 of High Resolution Gridded Data of Month-by-month Variation in Climate (January 1901-December 2014), retrieved from https://crudata.uea.ac.uk/cru/data/hrg/cru_ts_3.23/ cruts.1506241137.v3.23/, last access: May 2016) 
Herrmann, S. M., Anyamba, A., and Tucker, C. J.: Recent trends in vegetation dynamics in the African Sahel and their relationship to climate, Glob. Environ. Change, 15, 394-404, doi:10.1016/j.gloenvcha.2005.08.004, 2005.

Hickler, T., Eklundh, L., Seaquist, J. W., Smith, B., Ardö, J., Olsson, L., Sykes, M. T., and Sjöström, M.: Precipitation controls Sahel greening trend, Geophys. Res. Lett., 32, doi:10.1029/2005GL024370, 2005.

Hickler, T., Smith, B., Prentice, I. C., Mjofors, K., Miller, P., Arneth, A., and Sykes, M. T.: $\mathrm{CO}(2)$ fertilization in temperate FACE experiments not representative of boreal and tropical forests, Glob. Change Biol., 14, 1531-1542, doi:10.1111/j.13652486.2008.01598.x, 2008.

Hickler, T., Vohland, K., Feehan, J., Miller, P. A., Smith, B., Costa, L., Giesecke, T., Fronzek, S., Carter, T. R., and Cramer, W.: Projecting the future distribution of European potential natural vegetation zones with a generalized, tree species-based dynamic vegetation model, Glob. Ecol. Biogeogr., 21, 50-63, 2012.

Hollander, M. and Wolfe, D. A.: Nonparametric Statistical Methods, 2nd ed., John Wiley \& Sons, New York 35-140, 1999.

Huffman, G. J., Adler, R. F., Morrissey, M. M., Bolvin, D. T., Curtis, S., Joyce, R., McGavock, B., and Susskind, J.: Global precipitation at one-degree daily resolution from multisatellite observations, J. Hydrometeorol., 2, 36-50, 2001. (Datasets: GPCP 1-Degree Daily Combination (Version 1.2), retrieved from http: //precip.gsfc.nasa.gov/gpcp_daily_comb.html, last access: May 2016)

Jamali, S., Seaquist, J., Eklundh, L., and Ardö, J.: Automated mapping of vegetation trends with polynomials using NDVI imagery over the Sahel, Remote Sens. Environ., 141, 79-89, doi:10.1016/j.rse.2013.10.019, 2014.

Jones, C., Giorgi, F., and Asrar, G.: The Coordinated Regional Downscaling Experiment: CORDEX - an international downscaling link to CMIP5, Clivar Exchanges, 16, 34-40, 2011.

Joshi, M. M., Gregory, J. M., Webb, M. J., Sexton, D. M., and Johns, T. C.: Mechanisms for the land/sea warming contrast exhibited by simulations of climate change, Clim. Dynam., 30, 455-465, 2008.

Keenan, T. F., Hollinger, D. Y., Bohrer, G., Dragoni, D., Munger, J. W., Schmid, H. P., and Richardson, A. D.: Increase in forest water-use efficiency as atmospheric carbon dioxide concentrations rise, Nature, 499, 324-327, 2013.

Kgope, B. S., Bond, W. J., and Midgley, G. F.: Growth responses of African savanna trees implicate atmospheric $\left[\mathrm{CO}_{2}\right]$ as a driver of past and current changes in savanna tree cover, Austral Ecology, 35, 451-463, 2010.

Kjellström, E., Bärring, L., Gollvik, S., Hansson, U., Jones, C., Samuelsson, P., Rummukainen, M., Ullerstig, A., Willén, U., and Wyser, K.: A 140-year simulation of European climate with the new version of the Rossby Centre regional atmospheric climate model (RCA3), Reports Meteorology and Climatology, 108, SMHI, SE-60176 Norrkoping, Sweden, 54 pp., 2005.

Kjellström, E., Nikulin, G., Hansson, U., Strandberg, G., and Ullerstig, A.: 21st century changes in the European climate: uncertainties derived from an ensemble of regional climate model simulations, Tellus A, 63, 24-40, 2011.

Kucharski, F., Zeng, N., and Kalnay, E.: A further assessment of vegetation feedback on decadal Sahel rainfall variability, Clim. Dynam., 40, 1453-1466, 2013.
Lambert, F. H. and Chiang, J. C.: Control of land-ocean temperature contrast by ocean heat uptake, Geophys. Res. Lett., 34, doi:10.1029/2007GL029755, 2007.

Lambert, F. H., Webb, M. J., and Joshi, M. M.: The relationship between land-ocean surface temperature contrast and radiative forcing, J. Climate, 24, 3239-3256, 2011.

LaRow, T. E., Stefanova, L., and Seitz, C.: Dynamical simulations of north Atlantic tropical cyclone activity using observed lowfrequency SST oscillation imposed on CMIP5 Model RCP4. 5 SST projections, J. Climate, 27, 8055-8069, 2014.

Lawrence, D. and Vandecar, K.: Effects of tropical deforestation on climate and agriculture, Nature Climate Change, 5, 27-36, 2015.

Lindeskog, M., Arneth, A., Bondeau, A., Waha, K., Seaquist, J., Olin, S., and Smith, B.: Implications of accounting for land use in simulations of ecosystem carbon cycling in Africa, Earth Syst. Dynam., 4, 385-407, doi:10.5194/esd-4-385-2013, 2013.

Liu, Y. Y., van Dijk, A. I. J. M., de Jeu, R. A. M., Canadell, J. G., McCabe, M. F., Evans, J. P., and Wang, G.: Recent reversal in loss of global terrestrial biomass, Nature Climate Change, 5, 470-474, doi:10.1038/nclimate2581, 2015.

Long, S.: Modification of the response of photosynthetic productivity to rising temperature by atmospheric $\mathrm{CO}_{2}$ concentrations: has its importance been underestimated?, Plant, Cell Environ., 14, 729-739, 1991.

Moncrieff, G. R., Scheiter, S., Bond, W. J., and Higgins, S. I.: Increasing atmospheric $\mathrm{CO}_{2}$ overrides the historical legacy of multiple stable biome states in Africa, New Phytol., 201, 908-915, 2014.

Morales, P., Hickler, T., Rowell, D. P., Smith, B., and Sykes, M. T.: Changes in European ecosystem productivity and carbon balance driven by regional climate model output, Glob. Change Biol., 13, 108-122, 2007.

Moss, R. H., Edmonds, J. A., Hibbard, K. A., Manning, M. R., Rose, S. K., Van Vuuren, D. P., Carter, T. R., Emori, S., Kainuma, M., and Kram, T.: The next generation of scenarios for climate change research and assessment, Nature, 463, 747-756, 2010.

Nicholson, S. E. and Grist, J. P.: The seasonal evolution of the atmospheric circulation over West Africa and equatorial Africa, J. Climate, 16, 1013-1030, 2003.

Nikulin, G., Jones, C., Giorgi, F., Asrar, G., Büchner, M., CerezoMota, R., Christensen, O. B., Déqué, M., Fernandez, J., Hänsler, A., van Meijgaard, E., Samuelsson, P., Sylla, M. B., and Sushama, L.: Precipitation Climatology in an Ensemble of CORDEX-Africa Regional Climate Simulations, J. Climate, 25, 6057-6078, doi:10.1175/JCLI-D-11-00375.1, 2012.

Nogherotto, R., Coppola, E., Giorgi, F., and Mariotti, L.: Impact of Congo Basin deforestation on the African monsoon, Atmos. Sci. Lett., 14, 45-51, 2013.

Olsson, L., Eklundh, L., and Ardö, J.: A recent greening of the Sahel - trends, patterns and potential causes, J. Arid Environ., 63, 556566, 2005.

Pokam, W. M., Bain, C. L., Chadwick, R. S., Graham, R., Sonwa, D. J., and Kamga, F. M.: Identification of processes driving lowlevel westerlies in West Equatorial Africa, J. Climate, 27, 42454262, 2014.

Rayner, N., Parker, D. E., Horton, E., Folland, C., Alexander, L., Rowell, D., Kent, E., and Kaplan, A.: Global analyses of sea surface temperature, sea ice, and night marine air temperature since the late nineteenth century, J. Geophys. Res.-Atmos., 108, 
doi:10.1029/2002JD002670, 2003. (Datasets: Hadley Centre Sea Ice and Sea Surface Temperature data set (HadISST), retrieved from http://www.metoffice.gov.uk/hadobs/hadisst/, last access: May 2016)

Rowell, D. P.: Teleconnections between the tropical Pacific and the Sahel, Q. J. Roy. Meteorol. Soc., 127, 1683-1706, 2001.

Rowell, D. P.: Simulating SST teleconnections to Africa: What is the state of the art?, J. Climate, 26, 5397-5418, 2013.

Rummukainen, M.: State-of-the-art with regional climate models, Wiley Interdisciplinary Reviews: Climate Change, 1, 82-96, doi:10.1002/wcc.8, 2010.

Rummukainen, M.: Added value in regional climate modeling, Wiley Interdisciplinary Reviews: Climate Change, 7, 145-159, doi:10.1002/wcc.378, 2016.

Samuelsson, P., Gollvik, S., and Ullerstig, A.: The land-surface scheme of the Rossby Centre regional atmospheric climate model (RCA3), SMHI, 122, Norrkoping, Sweden, 2006.

Samuelsson, P., Jones, C. G., Willén, U., Ullerstig, A., Gollvik, S., Hansson, U., Jansson, C., Kjellström, E., Nikulin, G., and Wyser, K.: The Rossby Centre Regional Climate model RCA3: model description and performance, Tellus A, 63, 4-23, 2011.

Sankaran, M., Hanan, N. P., Scholes, R. J., Ratnam, J., Augustine, D. J., Cade, B. S., Gignoux, J., Higgins, S. I., Le Roux, X., and Ludwig, F.: Determinants of woody cover in African savannas, Nature, 438, 846-849, 2005.

Schefuß, E., Schouten, S., and Schneider, R. R.: Climatic controls on central African hydrology during the past 20,000 years, Nature, 437, 1003-1006, 2005.

Scheiter, S. and Higgins, S. I.: Impacts of climate change on the vegetation of Africa: an adaptive dynamic vegetation modelling approach, Glob. Change Biol., 15, 2224-2246, 2009.

Sitch, S., Huntingford, C., Gedney, N., Levy, P. E., Lomas, M., Piao, S. L., Betts, R., Ciais, P., Cox, P., Friedlingstein, P., Jones, C. D., Prentice, I. C., and Woodward, F. I.: Evaluation of the terrestrial carbon cycle, future plant geography and climate-carbon cycle feedbacks using five Dynamic Global Vegetation Models (DGVMs), Glob. Change Biol., 14, 2015-2039, doi:10.1111/j.1365-2486.2008.01626.x, 2008.

Smith, B., Prentice, I. C., and Sykes, M. T.: Representation of vegetation dynamics in the modelling of terrestrial ecosystems: comparing two contrasting approaches within European climate space, Glob. Ecol. Biogeogr., 10, 621-637, doi:10.1046/j.1466822X.2001.t01-1-00256.x, 2001.

Smith, B., Samuelsson, P., Wramneby, A., and Rummukainen, M.: A model of the coupled dynamics of climate, vegetation and terrestrial ecosystem biogeochemistry for regional applications, Tellus A, 63, 87-106, doi:10.1111/j.1600-0870.2010.00477.x, 2011.

Smith, B., Wårlind, D., Arneth, A., Hickler, T., Leadley, P., Siltberg, J., and Zaehle, S.: Implications of incorporating $\mathrm{N}$ cycling and $\mathrm{N}$ limitations on primary production in an individualbased dynamic vegetation model, Biogeosciences, 11, 20272054, doi:10.5194/bg-11-2027-2014, 2014.

Sörensson, A. A. and Menéndez, C. G.: Summer soil-precipitation coupling in South America, Tellus A, 63, 56-68, 2011.

Sultan, B. and Janicot, S.: The West African monsoon dynamics. Part II: The "preonset" and "onset" of the summer monsoon, J. Climate, 16, 3407-3427, 2003.
Sutton, R. T., Dong, B., and Gregory, J. M.: Land/sea warming ratio in response to climate change: IPCC AR4 model results and comparison with observations, Geophys. Res. Lett., 34, doi:10.1029/2006GL028164, 2007.

Sylla, M., Giorgi, F., Ruti, P., Calmanti, S., and Dell'Aquila, A.: The impact of deep convection on the West African summer monsoon climate: a regional climate model sensitivity study, Q. J. Roy. Meteorol. Soc., 137, 1417-1430, 2011.

Taylor, K. E., Stouffer, R. J., and Meehl, G. A.: An overview of CMIP5 and the experiment design, B. Am. Meteorol. Soc., 93, 485-498, 2012.

Texier, D., De Noblet, N., Harrison, S., Haxeltine, A., Jolly, D., Joussaume, S., Laarif, F., Prentice, I., and Tarasov, P.: Quantifying the role of biosphere-atmosphere feedbacks in climate change: coupled model simulations for 6000 years BP and comparison with palaeodata for northern Eurasia and northern Africa, Clim. Dynam., 13, 865-881, 1997.

Thonicke, K., Venevsky, S., Sitch, S., and Cramer, W.: The role of fire disturbance for global vegetation dynamics: coupling fire into a Dynamic Global Vegetation Model, Glob. Ecol. Biogeogr., 10, 661-677, doi:10.1046/j.1466-822X.2001.00175.x, 2001.

Tokinaga, H., Xie, S.-P., Deser, C., Kosaka, Y., and Okumura, Y. M.: Slowdown of the Walker circulation driven by tropical IndoPacific warming, Nature, 491, 439-443, 2012.

Wang, G. and Alo, C. A.: Changes in precipitation seasonality in West Africa predicted by RegCM3 and the impact of dynamic vegetation feedback, International J. Geophys., 2012, doi:10.1155/2012/597205, 2012.

Wang, G. and Eltahir, E. A.: Biosphere - atmosphere interactions over West Africa. II: Multiple climate equilibria, Q. J. Roy. Meteorol. Soc., 126, 1261-1280, 2000.

Wang, G., Eltahir, E., Foley, J., Pollard, D., and Levis, S.: Decadal variability of rainfall in the Sahel: results from the coupled GENESIS-IBIS atmosphere-biosphere model, Clim. Dynam., 22, 625-637, 2004.

Wårlind, D., Smith, B., Hickler, T., and Arneth, A.: Nitrogen feedbacks increase future terrestrial ecosystem carbon uptake in an individual-based dynamic vegetation model, Biogeosciences, 11, 6131-6146, doi:10.5194/bg-11-6131-2014, 2014.

Weber, U., Jung, M., Reichstein, M., Beer, C., Braakhekke, M. C., Lehsten, V., Ghent, D., Kaduk, J., Viovy, N., Ciais, P., Gobron, N., and Rödenbeck, C.: The interannual variability of Africa's ecosystem productivity: a multi-model analysis, Biogeosciences, 6, 285-295, doi:10.5194/bg-6-285-2009, 2009.

Wramneby, A., Smith, B., and Samuelsson, P.: Hot spots of vegetation-climate feedbacks under future greenhouse forcing in Europe, J. Geophys. Res., 115, D21119, doi:10.1029/2010jd014307, 2010.

Wu, M., Knorr, W., Thonicke, K., Schurgers, G., Camia, A., and Arneth, A.: Sensitivity of burned area in Europe to climate change, atmospheric $\mathrm{CO}_{2}$ levels and demography: A comparison of two fire-vegetation models, J. Geophys. Res.-Biogeosci., 120, 22562272, doi:10.1002/2015JG003036, 2015.

Xu, Z., Chang, P., Richter, I., and Tang, G.: Diagnosing southeast tropical Atlantic SST and ocean circulation biases in the CMIP5 ensemble, Clim. Dynam., 43, 3123-3145, 2014.

Young, I.: Seasonal variability of the global ocean wind and wave climate, Int. J. Climatol., 19, 931-950, 1999. 
Yu, M., Wang, G., and Pal, J. S.: Effects of vegetation feedback on future climate change over West Africa, Clim. Dynam., 46, 3669-3688, doi:10.1007/s00382-015-2795-7, 2015.

Zeng, N., Neelin, J. D., Lau, K.-M., and Tucker, C. J.: Enhancement of interdecadal climate variability in the Sahel by vegetation interaction, Science, 286, 1537-1540, 1999.

Zhang, W., Jansson, C., Miller, P. A., Smith, B., and Samuelsson, P.: Biogeophysical feedbacks enhance the Arctic terrestrial carbon sink in regional Earth system dynamics, Biogeosciences, 11, 5503-5519, doi:10.5194/bg-11-5503-2014, 2014.
Zhou, L., Tian, Y., Myneni, R. B., Ciais, P., Saatchi, S., Liu, Y. Y., Piao, S., Chen, H., Vermote, E. F., Song, C., and Hwang, T.: Widespread decline of Congo rainforest greenness in the past decade, Nature, 509, 86-90, doi:10.1038/nature13265, 2014.

Zhu, Z., Bi, J., Pan, Y., Ganguly, S., Anav, A., Xu, L., Samanta, A., Piao, S., Nemani, R. R., and Myneni, R. B.: Global data sets of vegetation leaf area index (LAI) $3 g$ and Fraction of Photosynthetically Active Radiation (FPAR) 3g derived from Global Inventory Modeling and Mapping Studies (GIMMS) Normalized Difference Vegetation Index (NDVI3g) for the period 1981 to 2011, Remote Sensing, 5, 927-948, 2013. (Datasets: 30+ Years of LAI3g and FPAR3g Data Sets, retrieved from http://cliveg.bu. edu/modismisr/lai3g-fpar3g.html, last access: May 2016) 